BMC

Plant Biology

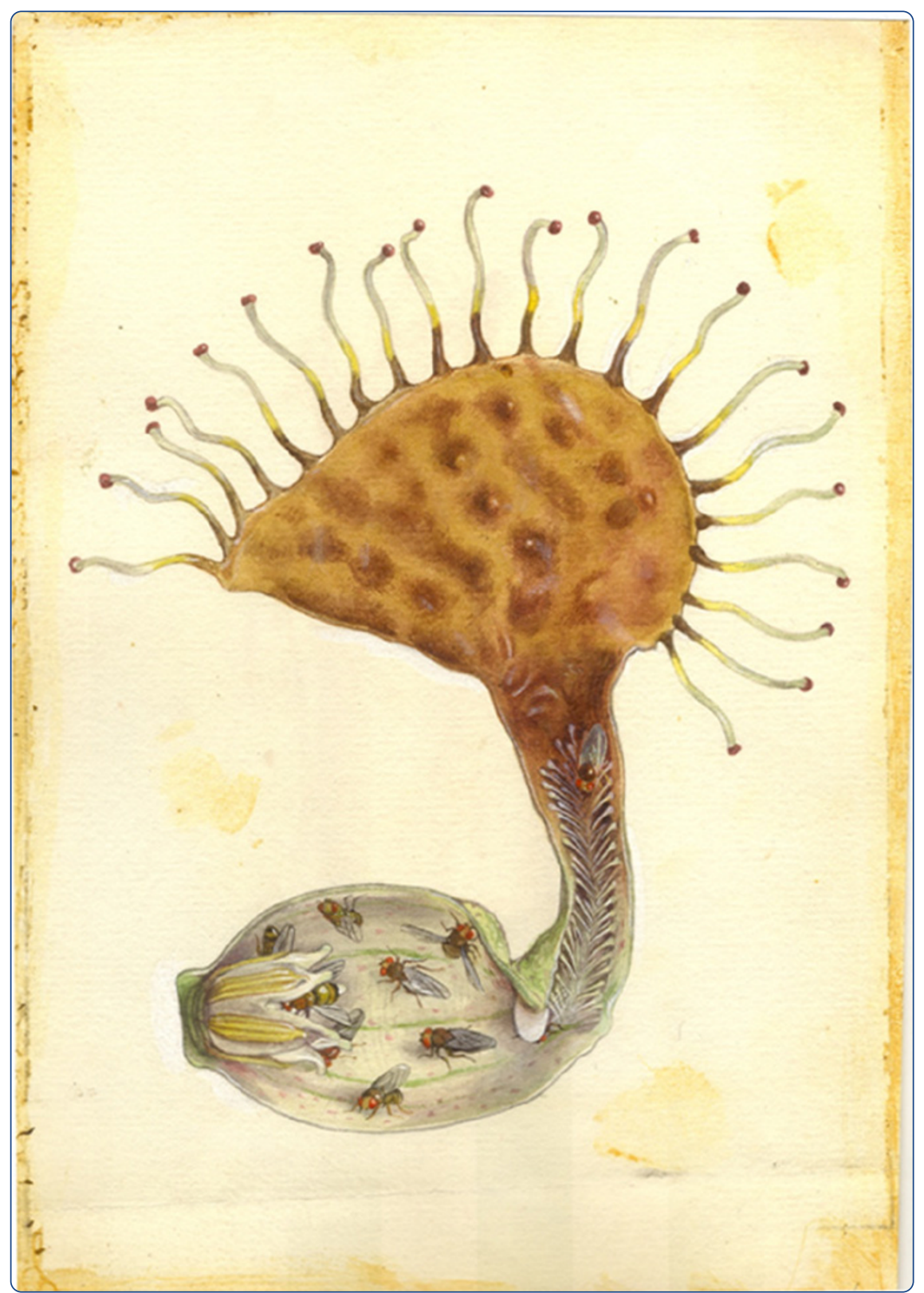

Characterization of the basal angiosperm Aristolochia fimbriata: a potential experimental system for genetic studies

Bliss et al. 


\title{
Characterization of the basal angiosperm Aristolochia fimbriata: a potential experimental system for genetic studies
}

\author{
Barbara J Bliss ${ }^{1,2^{*}+}$, Stefan Wanke ${ }^{3 \dagger}$, Abdelali Barakat ${ }^{1,4}$, Saravanaraj Ayyampalayam ${ }^{5}$, Norman Wickett ${ }^{1,6}$, \\ P Kerr Wall ${ }^{1,7}$, Yuannian Jiao ${ }^{1}$, Lena Landherr ${ }^{1}$, Paula E Ralph ${ }^{1}$, Yi Hu$^{1}$, Christoph Neinhuis ${ }^{3}$, Jim Leebens-Mack ${ }^{5}$, \\ Kathiravetpilla Arumuganathan ${ }^{8}$, Sandra W Clifton ${ }^{9,10}$, Siela N Maximova ${ }^{11}$, Hong Ma,12,13 \\ and Claude $\mathrm{W}$ dePamphilis ${ }^{1 *}$
}

\begin{abstract}
Background: Previous studies in basal angiosperms have provided insight into the diversity within the angiosperm lineage and helped to polarize analyses of flowering plant evolution. However, there is still not an experimental system for genetic studies among basal angiosperms to facilitate comparative studies and functional investigation. It would be desirable to identify a basal angiosperm experimental system that possesses many of the features found in existing plant model systems (e.g., Arabidopsis and Oryza).

Results: We have considered all basal angiosperm families for general characteristics important for experimental systems, including availability to the scientific community, growth habit, and membership in a large basal angiosperm group that displays a wide spectrum of phenotypic diversity. Most basal angiosperms are woody or aquatic, thus are not well-suited for large scale cultivation, and were excluded. We further investigated members of Aristolochiaceae for ease of culture, life cycle, genome size, and chromosome number. We demonstrated self-compatibility for Aristolochia elegans and A. fimbriata, and transformation with a GFP reporter construct for Saruma henryi and A. fimbriata. Furthermore, A. fimbriata was easily cultivated with a life cycle of just three months, could be regenerated in a tissue culture system, and had one of the smallest genomes among basal angiosperms. An extensive multi-tissue EST dataset was produced for A. fimbriata that includes over 3.8 million 454 sequence reads.

Conclusions: Aristolochia fimbriata has numerous features that facilitate genetic studies and is suggested as a potential model system for use with a wide variety of technologies. Emerging genetic and genomic tools for $A$. fimbriata and closely related species can aid the investigation of floral biology, developmental genetics, biochemical pathways important in plant-insect interactions as well as human health, and various other features present in early angiosperms.
\end{abstract}

\footnotetext{
* Correspondence: bjbliss@gmail.com; cwd3@psu.edu

${ }^{\dagger}$ Equal contributors

${ }^{1}$ Department of Biology, Institute of Molecular Evolutionary Genetics, and the

Huck Institutes of the Life Sciences, 201 Life Sciences Building, Pennsylvania

State University, University Park, PA 16802, USA

2USDA ARS PBARC, 64 Nowelo St., Hilo, HI 96720, USA

Full list of author information is available at the end of the article
} 
Table 1 A summary of relevant basal angiosperm characteristics

\begin{tabular}{|c|c|c|c|c|c|}
\hline Order & Family $^{1,2}$ & \# Genera / species $^{3}$ & Familiar genera $^{3}$ & Growth form $^{1,2}$ & Commercially available \\
\hline AMBORELLALES & Amborellaceae & $1 / 1$ & Amborella & shrub & no \\
\hline \multirow[t]{9}{*}{ NYMPHAEALES } & Nymphaeaceae & $5 / 58$ & Nymphaea & aquatic herb & yes \\
\hline & & & Nuphar & & \\
\hline & & & Barclaya & & \\
\hline & & & Victoria & & \\
\hline & & & Euryale & & \\
\hline & Cabombaceae & $2 / 6$ & Cabomba & aquatic herb & yes \\
\hline & & & Brassenia & & \\
\hline & Hydatellaceae & $2 / 10$ & Hydatella & aquatic herb & no \\
\hline & & & Trithuria & & \\
\hline \multirow[t]{5}{*}{ AUSTROBAILEYALES } & Austrobaileyaceae & $1 / 2$ & Austrobaileya & liana & no \\
\hline & Illiciaceae & $3 / 92$ & Illicium & shrub, tree & yes \\
\hline & & & Schisandra & & \\
\hline & & & Kadsura & & \\
\hline & Trimeniaceae & $1-2 / 6$ & Trimenia & shrub, tree, liana & no \\
\hline CERATOPHYLLALES & Ceratophyllaceae & $1 / 6$ & Ceratophyllum & aquatic herb & yes \\
\hline \multirow[t]{4}{*}{ CHLORANTHALES } & Chloranthaceae & $4 / 75$ & Chloranthus & herb, shrub, tree & no \\
\hline & & & Ascarina & & \\
\hline & & & Hedyosmum & & \\
\hline & & & Sarcandra & & \\
\hline \multirow[t]{17}{*}{ MAGNOLIALES } & Annonaceae & $129 / 2220$ & Annona & shrub, tree, liana & yes \\
\hline & & & Guatteris & & \\
\hline & & & Xylopia & & \\
\hline & & & Uvaria & & \\
\hline & & & Polyalthia & & \\
\hline & & & Rollinia & & \\
\hline & & & Artabotrys & & \\
\hline & & & Asimina & & \\
\hline & Eupomatiaceae & $1 / 3$ & Eupomatia & shrub, tree & yes \\
\hline & Magnoliaceae & $2 / 227$ & Magnolia & shrub, tree & yes \\
\hline & & & Lioriodendron & & \\
\hline & Degeneriaceae & $1 / 2$ & Degeneria & tree & no \\
\hline & Himantandraceae & $1 / 2$ & Galbulimima & tree & no \\
\hline & Myristicaceae & $20 / 475$ & Myristica & shrub, tree & yes \\
\hline & & & Horsfieldia & & \\
\hline & & & Virola & & \\
\hline & & & Knema & & \\
\hline \multirow[t]{6}{*}{ LAURALES } & Calycanthaceae & $5 / 11$ & Chimonanthus & shrub, tree & yes \\
\hline & & & Calycanthus & & \\
\hline & & & Idiospermum & & \\
\hline & & & Sinocalycanthus & & \\
\hline & Hernandiaceae & $5 / 55$ & Hernandia & shrub, tree, liana & no \\
\hline & & & Illigera & & \\
\hline
\end{tabular}


Table 1 A summary of relevant basal angiosperm characteristics (Continued)

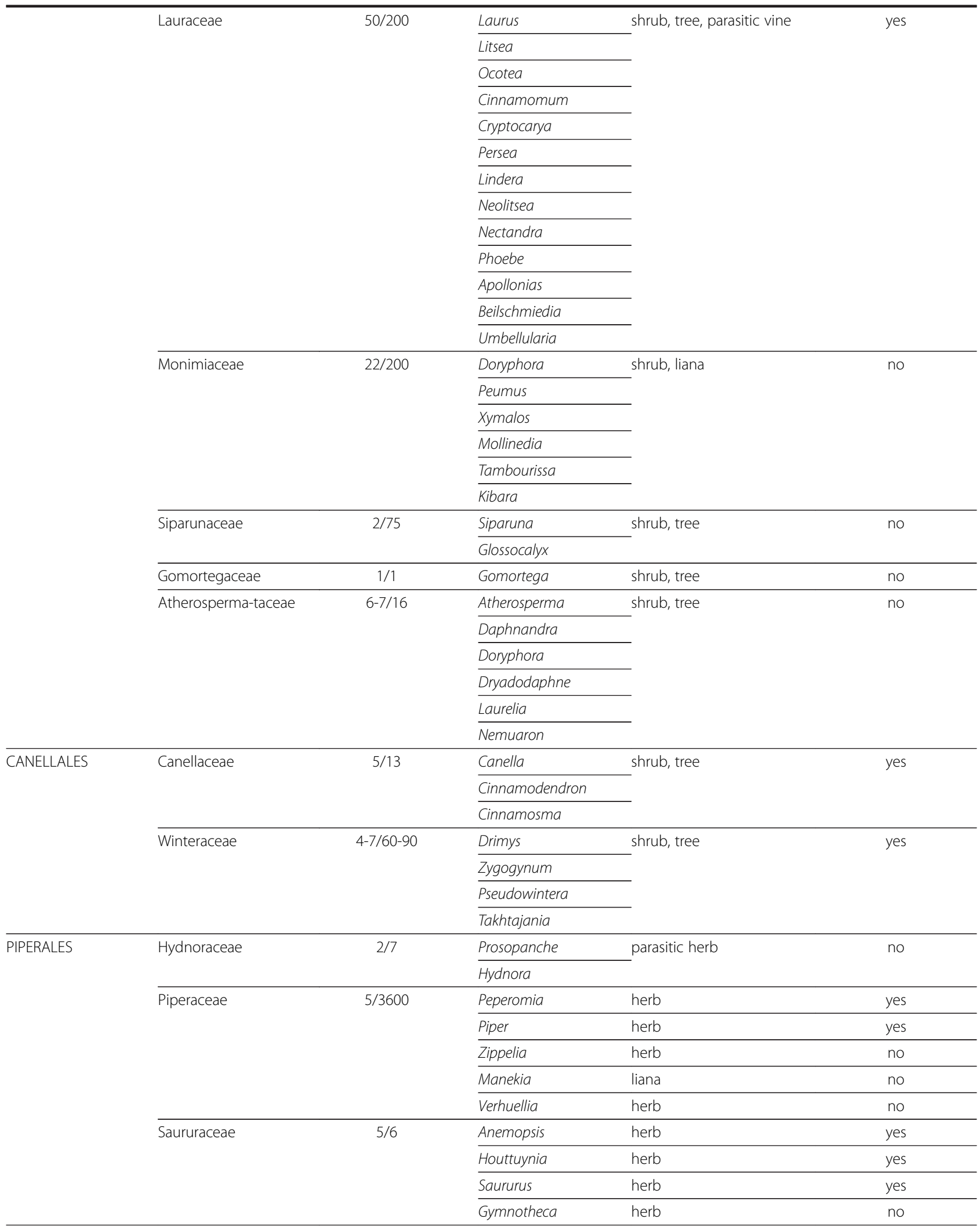


Table 1 A summary of relevant basal angiosperm characteristics (Continued)

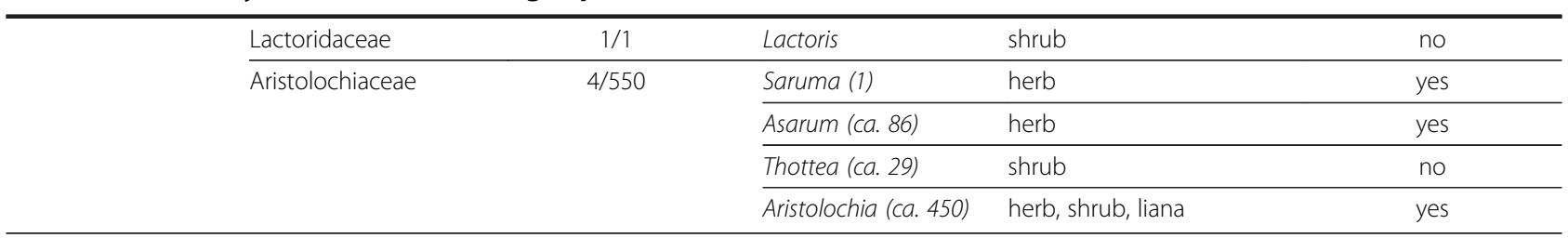

Familiar genera include representatives from the family and are not intended to comprise a comprehensive listing. Taxa are considered "commercially available" if one hundred plants or more can be purchased, inexpensively, and can be readily propagated from seed.

1 [9].

${ }^{2}[17]$.

${ }^{3}$ Number of species shown for Aristolochiaceae genera from [18].

\section{Background}

Our present understanding of genetics, genomics, development, evolution, and physiology of living organisms has benefited greatly from work done in model genetic systems. Model systems provide more favorable conditions for observing phenomena and testing hypotheses than other systems afford. Models support inductive reasoning, in which one builds on the understanding of living organisms in general, based on observations made in a specific model organism [1]. Model organisms also provide a focus for researchers to work on a common system, resulting in collaborative and complementary efforts that can yield rapid progress and development of further resources. Models are crucial for understanding basic biological processes.

Model organisms should have several key attributes. They should share a number of characteristics of the taxon or process they are chosen to represent [1,2] and must be accessible [2] so that a broad community of scientists can utilize and develop them. Models used for developmental and genetic studies must also offer rapid development, short generation time, be amenable to large scale cultivation, have small seed size for easy storage of many genotypes, and provide ample tissue for experimentation [1]. Models should also support forward and reverse genetics, as is required for hypothesis testing [3], and have a small genome size to facilitate molecular genetics and genomics work, including genome sequencing and assembly [4,5]. Finally, for studying the evolution of development, models should have both conserved and unique features in comparison to related species, so that comparative studies can elucidate the mechanisms of phenotypic evolution [6].

Our current understanding of angiosperm evolution has been shaped by multiple phylogenetic studies eg., [7-9] that provide the organismal context in which the evolution of any aspect of flowering plants is studied. Of particular interest to both basic and applied plant biology are changes leading to the success and diversification of angiosperm lineages, beginning with the early, mostly speciespoor lineages of angiosperms (Table 1) previously known as the ANITA grade (Amborellaceae, Nymphaeales,
Illiciaceae, Trimeniaceae, and Austrobaileyaceae), followed by the magnoliids (Figure 1). The genome of the shrub Amborella trichopoda, the likely singular living sister group to the rest of the living angiosperms, has been mapped [10] and sequenced (www.Amborella.org), providing an ideal root for comparative genomic studies of all other angiosperms [11]. The magnoliids contain four major branches and several thousand species (Table 1, Figure 1). Among the species in this lineage are the ornamental tree, Liriodendron tulipfera [12] and the fruit tree, Persea americana [13], as well as the economically important spice, black pepper (Piper nigrum) [14]. Taxa included in the magnoliids exhibit many features first appearing in basal angiosperms or angiosperms in general e.g., vessel elements, perianth bilateral symmetry, alkaloid chemistry, specialized pollination systems, and diverse forms of female gametophyte development $[3,15,16]$. Recent phylogenetic studies have suggested that the magnoliids are the sister clade and therewith the closest outgroup to the species-rich and highly diverged monocot and eudicot lineages [7-9].

The rich diversity of basal angiosperms provides glimpses into early successful experiments in angiosperm adaptation [3,19-23]. Novel features which are otherwise constrained by function may have evolved more than once, through parallelism and convergence, such as the structural and developmental similarities of the inflorescence of the monocot Acorus with that found in some Piperales (Piperaceae, Saururaceae; members of Magnoliids) [24]. Basal lineages also retain evidence of "trials" of features that became genetically fixed in later lineages [25]. For example, perianth parts are quite variable in basal angiosperms, as well as in basal eudicots and basal monocots [26], and only became canalized later on.

Current flowering plant genetic models are all derived from the highly diverged monocot and eudicot lineages (Figure 1). Among them, the monocot models Zea and Oryza occur in Poaceae, which has specialized floral organs and an inflorescence found only in that family. Similarly, the current eudicot models are derived from the rosid (Arabidopsis) and asterid (e.g., Antirrhinum, 


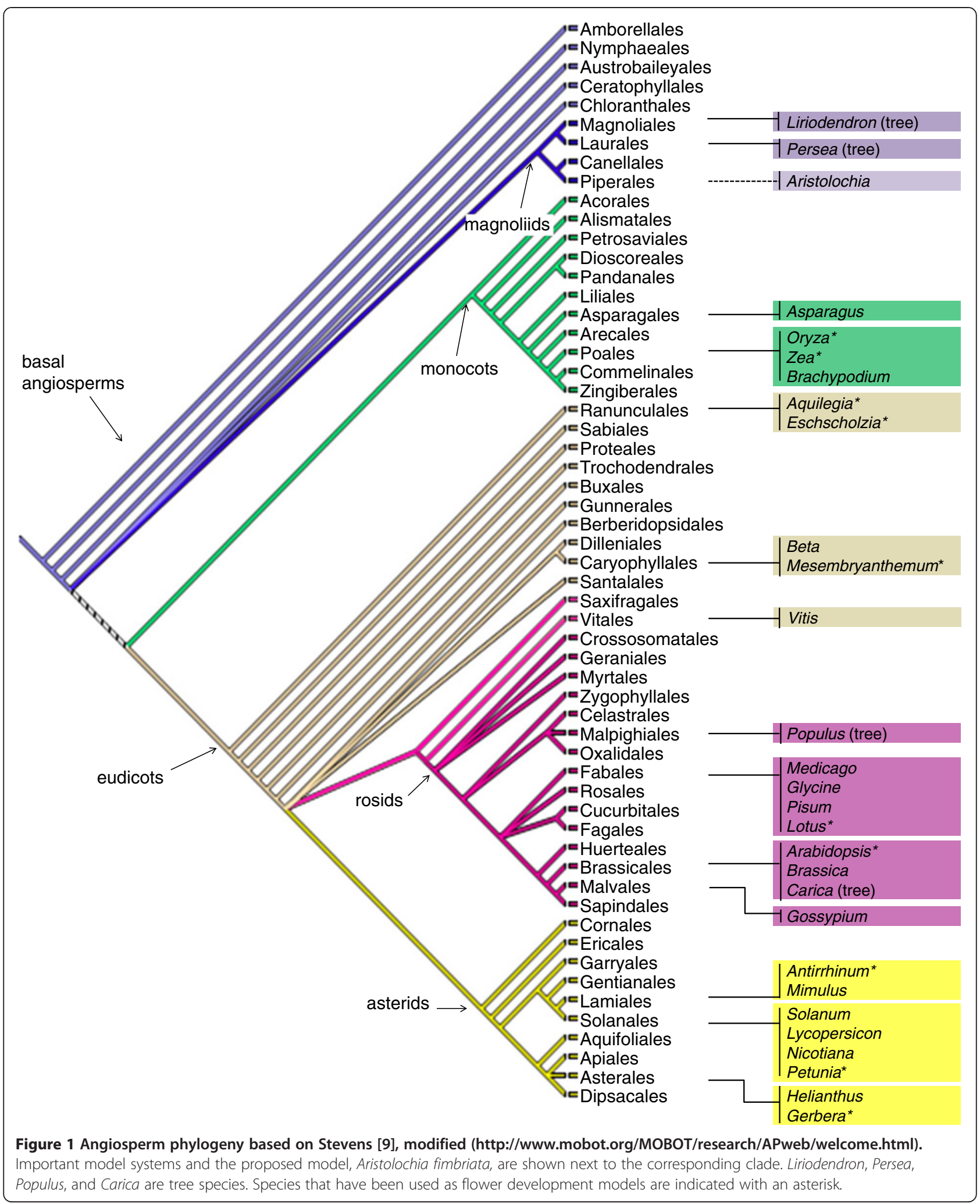


tomato) "core eudicot" lineages, each of which displays lineage-specific floral forms [25,27]. Studies in current plant models have led to the discovery of broadly homologous traits, including conservation of floral organ identity genes (ABC/quartet models) [28-30]. These homologies, and others observed in current plant models (Figure 1), have suggested hypotheses about the common ancestor of monocots and eudicots.

An understanding of the evolution of floral development or any fundamental process in flowering plants should include results from a basal angiosperm experimental model in which functional hypotheses can be tested [3,6,31-33]. Although the current model systems represent well the highly successful and derived lineages in which they occur, they do not represent the overall diversity of angiosperms. Information from basal lineages is necessary to better describe that diversity, to polarize the changes that occurred during angiosperm evolution, and to make functional inferences about the common ancestor of early angiosperms.

Current plant models have been selected to address particular questions, but very few are available for use both as genomic and as genetic models. Genomic resources, which emphasize plants with relatively small genomes, have been developed for tree wood and fruit species, including Populus [34], Liriodendron [12], Persea [35] and Carica [36]. However, woody species are too large at maturity and do not have short enough life cycles for general use in genetic experiments. Forward genetics requires a very small organism with a rapid life cycle, and is facilitated by the ability to self-pollinate individuals having desired characteristics. Reverse genetics requires manipulation of DNA or RNA in a targeted manner. Both benefit from a small genome, and transformability is essential for testing hypotheses about gene function. Therefore, we sought to identify a basal angiosperm species having as many important features of a model system as possible to support its potential development into an experimental system in genetics and genomics. We present these essential features in Aristolochia fimbriata - small size at maturity, rapid life cycling, self-compatibilty, small genome size, and transformability - along with relevant findings for other taxa evaluated in our study.

\section{Results}

\section{Evaluation of potential models in basal angiosperm} orders and families

We followed a formal selection process to identify a suitable candidate for an experimental organism among basal angiosperms (Figure 2). Many basal angiosperms are uncommon, with limited distribution, and often occur in families with only one genus and few species (Table 1). Taxa were considered readily accessible to a broad scientific community if they could be obtained commercially at a low price and could be readily propagated by seed. Those of limited availability were eliminated, including Amborellales (Amborellaceae), Austrobaileyales (Illiciaceae, Austrobaileyaceae, Trimeniaceae), and Chloranthales (Chloranthaceae) (Figure 2).

Next, we eliminated groups of plants sharing a growth habit associated with barriers for use as a genetic model. Woody plants requiring a year or more to attain maturity, as well as extensive space for cultivation, were eliminated (Figure 2). These included most Magnoliales (Myristicaceae, Magnoliaceae, Annonaceae, Himantandraceae, Degeneriaceae, Eupomatiaceae), Laurales (Lauraceae, Hernandiaceae, Monimiaceae, Atherospermataceae, Gomortegaceae, Siparunaceae, Calycanthaceae), and Cannellales (Cannellaceae, Winteraceae). The forest tree species, Liriodendron (Magnoliaceae) and the fruit tree Persea (Lauraceae), were among those eliminated due to woody habit and long generation time. Many of the families listed above would also be eliminated due to limited commercial availability, as e.g., Trimeniaceae, Himantandraceae, and Gomortegaceae (Table 1). Similarly, many of the families eliminated for limited accessibility have a woody habit (Table 1); these would have been eliminated for that character even if they had been more accessible (e.g., Amborella trichopoda). Plants with an aquatic habit, including water lilies (Nymphaeales: Nymphaceae, Cabombaceae) and Ceratophyllum (Ceratophyllales: Ceratophyllaceae), were eliminated due to the extensive cultivation requirements associated with maintaining large numbers of individual aquatic plants, as well as the difficulty in developing selfpollination and transformation protocols in an aquatic environment (Figure 2). Orders composed entirely of woody or aquatic plants were eliminated after review and consideration of the species comprising them.

The order Piperales (Aristolochiaceae, Hydnoraceae, Piperaceae, Saururaceae, Lactoridaceae) contains several herbaceous taxa (Table 1). Parasitic plants (Hydnoraceae) and those with highly reduced flowers (Saururaceae, Piperaceae) do not generally represent angiosperms, and so were eliminated (Figure 2). Hydnoraceae and Lactoridaceae would also be excluded due to limited availability (Table 1). Among the basal angiosperm families, only Aristolochiaceae contains highly accessible, easily cultivated herbaceous plants with features broadly representative of angiosperms in general.

\section{Aristolochiaceae candidates considered}

We surveyed Aristolochiaceae, seeking species with rapid growth, no requirement for vernalization in the life cycle, ease of large scale cultivation, and a small genome size to facilitate gene function studies and genome sequencing and assembly (Figure 2). Members of genus Aristolochia have some of the smallest basal angiosperm genome sizes currently known (Figure 3 ). Therefore, we 


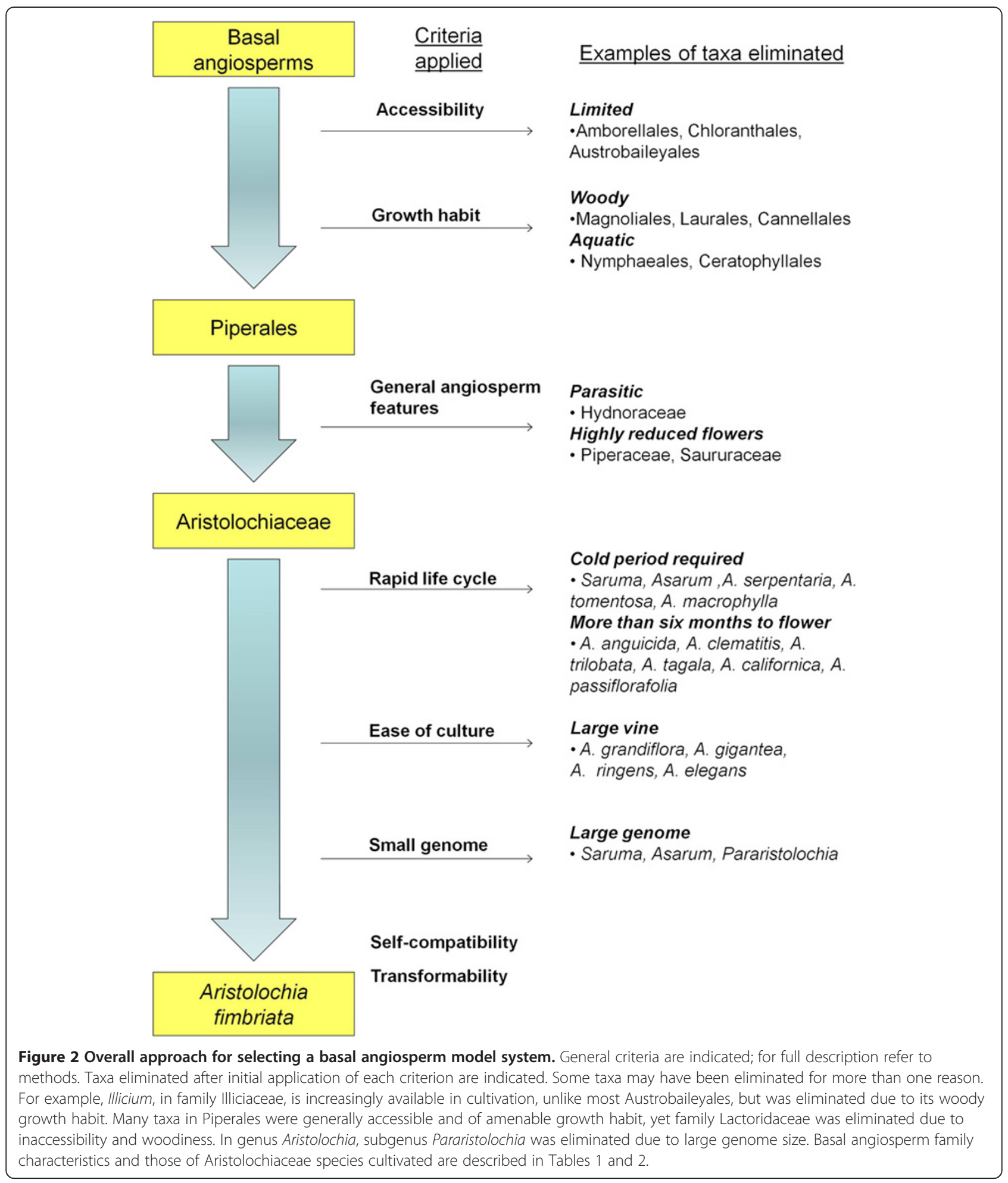

evaluated each genus in this family to identify the best species for model system development. Subfamily Asaroideae genera (Asarum, Saruma) (Figure 4A and B) require cold treatment to induce flowering, resulting in increased culturing efforts and extended time to flower, so they were eliminated (Figure 2). Thottea, here represented with T. siliquosa (Figure 4C), was not possible to obtain for a detailed cultural survey (Table 2), as it can only be cultivated with very high maintenance, under a narrow range of conditions. Furthermore, it grows 


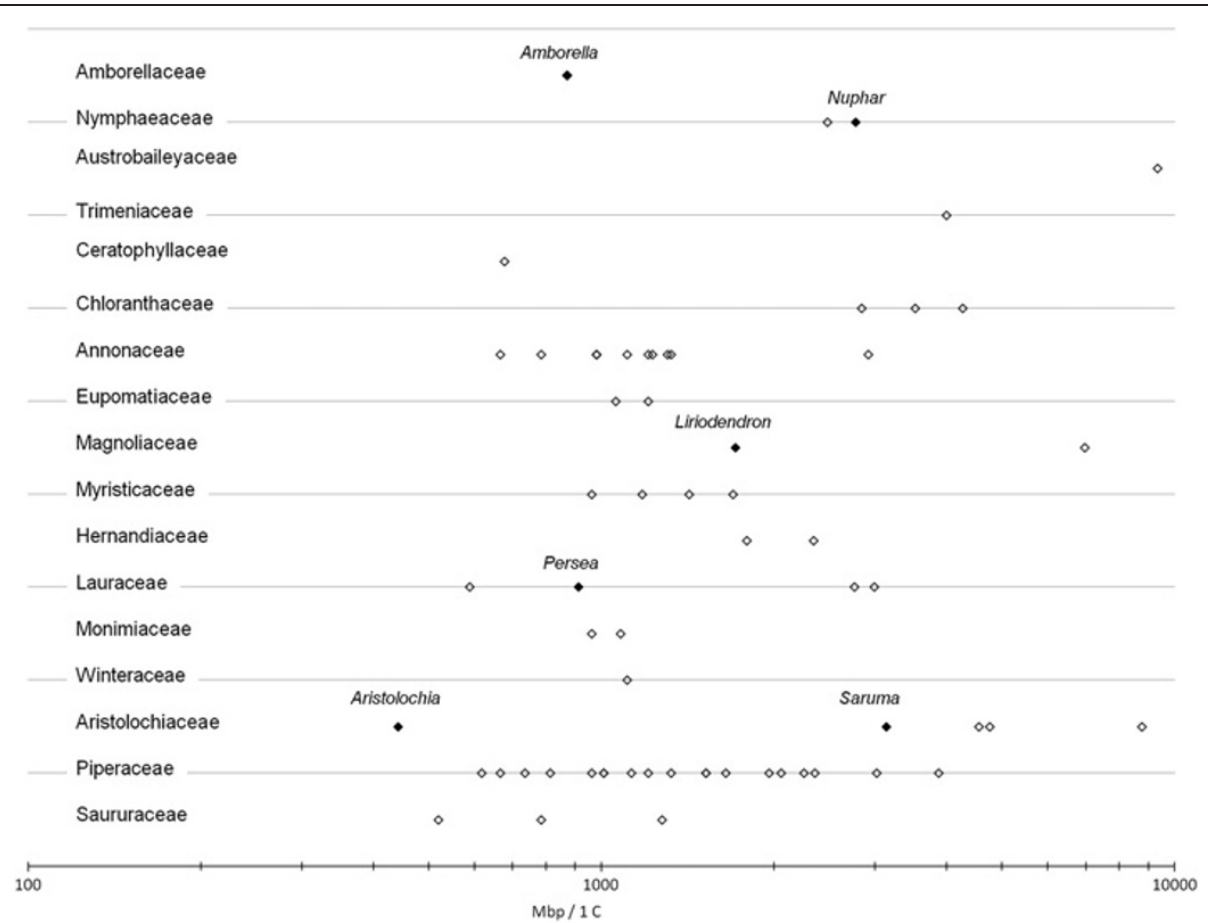

Figure 3 Genome sizes in basal angiosperm families. Bennett and Leitch [38] updated with Cui et al. [39], shown on logarithmic scale. Filled symbols indicate taxa used in The Floral Genome Project (www.floralgenome.org) or The Ancestral Angiosperm Genome Project (http://ancangio. uga.edu/), and for which EST resources are available. Compare basal angiosperm genome sizes to Arabidopsis at 125 Mb [40] and Oryza at 389 $\mathrm{Mb}$ [41]. The symbol representing Aristolochia is the proposed model Aristolochia fimbriata. Other species of Aristolochia have smaller genome sizes (see Figure 5, Table 4).

slowly, produces little tissue, few flowers, and few seeds. Of the Aristolochia species available for culturing, those requiring cold treatment (e.g. A. serpentaria, other members of subgenus Isotrema and A. clematitis, Figure 4D) were eliminated from consideration. Members of subgenus Pararistolochia (Figure 4E) were not available for culturing or are large vines with a long life cycle. Those species that did not bloom in six months (A. californica, A. anguicida, A. macrophylla, A. tomentosa), produced very few flowers (A. trilobata, A. passiflorafolia; Figure $4 \mathrm{~F}$ and $\mathrm{G}$ ), or formed very large vines (A. grandiflora, A. ringens, A. labiata, A. gigantea) (Table 2, Figure 2) were also eliminated. The remaining candidates that met our criteria were two smaller members of subgenus Aristolochia (A. elegans and A. fimbriata), belonging to a group of subtropical and tropical species from South and Central America [18,37].

\section{A phylogenetic perspective of genome sizes}

Because a small genome size facilitates molecular and functional investigation of genes of interest, including cloning and characterization of both coding and regulatory regions, and genome sequencing and assembly, our analysis of genome size evolution in Aristolochiaceae focused on species having small genomes, particularly in subgenus Aristolochia, for which we report here the smallest genome size to date from a basal angiosperm (A. lindneri) (Figure 5). In order to gain insight into the evolution of genome structure as well as genome size in Aristolochiaceae, chromosome numbers from previously published studies $[43,44]$ were plotted along with genome sizes on a strict consensus tree using TreeGraph [45] (Figure 5, see also Additional file 1: Phylogram of Aristolochiaceae relationships).

A direct correlation between chromosome numbers and genome size for the family of Aristolochiaceae was not observed. Aristolochiaceae is subdivided into two subfamilies, Asaroideae and Aristolochioideae. Asaroideae, which has $2 \mathrm{n}=26,52$ (Saruma henryi) and $2 \mathrm{n}=26$ (Asarum caudatum) chromosomes, has about two to ten times the genome size of genus Aristolochia (Figure 5). Thottea, the earliest diverging branch in subfamily Aristolochioideae has the same number of chromosomes $(2 \mathrm{n}=26)$ as Asarum and Saruma, but has only $1 / 9$ and $1 / 5$ of the genome size of Asarum and Saruma, respectively.

In contrast, within genus Aristolochia, species in subgenus Aristolochia exhibit the smallest genome sizes, but have a wide range of chromosome numbers. Species in subgenus Isotrema (Figure 4D) are generally characterized by $2 \mathrm{n}=32$ chromosomes and have small genome sizes (554-774 Mbp mean genome size, 1C). Within subgenus Pararistolochia (Figure 4E) (1793-4321 Mbp mean 

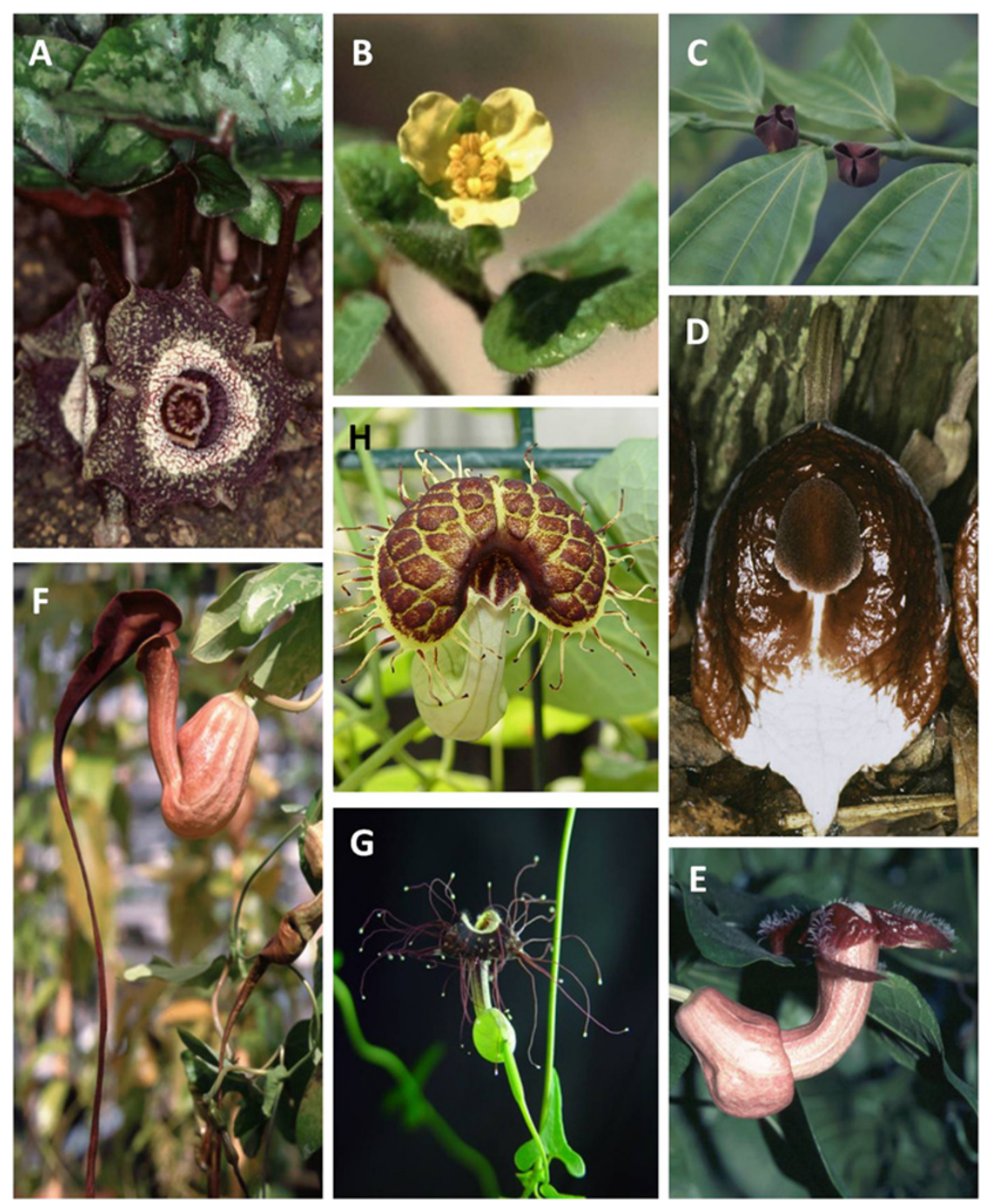

Figure 4 Diversity of flower and growth forms in Aristolochiaceae. Herbaceous perennials with radially symmetric 3-merous flowers include A. Asarum chingchengense B. Saruma henryi C. Thottea siliquosa, a small shrub D. A. arborea (subgenus Isotrema), a tree-like shrub with flowers that mimic fungi E. A. triactina (subgenus Pararistolochia) F. A. trilobata (subgenus Aristolochia) with three lobed, evergreen leaves, grows as a vine with woody branches (liana) from which new growth emerges. G. A. passiflorafolia (subgenus Aristolochia) (photo used with permission from Changbin Chen) and H. A. fimbriata (subgenus Aristolochia).

genome size, 1C), which is sister group to subgenus Aristolochia, and therefore nested within the clade having species with small genomes, a lineage-specific increase in genome size can be seen. The increase is not associated with an increase in chromosome number, but in chromosome size [43]. The Australian species of Pararistolochia have less than half of the genome size of the African species, but still have the same number of chromosomes [43]. Within the subgenus Aristolochia (Figure 4F, G and $\mathrm{H}$ ), the different monophyletic groups recovered (Figure 5; see also Additional file 1: Phylogram of Aristolochiaceae relationships) are in accordance with previous studies $[14,18]$. It is interesting to note that Asarum and subgenus Pararistolochia have large chromosomes similar to those of monocots, whereas the remaining clades in Aristolochiaceae have small chromosomes [43]. Aristolochia fimbriata is a member of a clade of Aristolochia species with $2 \mathrm{n}=14$ chromosomes and genomes roughly the size of Oryza sativa.

\section{Methods for genetics}

We further evaluated selected taxa for self-compatibility and potential for genetic engineering, both of which are critical features of genetic systems. Self-pollination 
Table 2 Cultivation features for $\mathbf{2 5}$ Aristolochiaceae taxa considered

\begin{tabular}{|c|c|c|c|c|}
\hline Taxon & Floral productivity & Low maintenance & Dormancy required & Reported self fertile $^{1}$ \\
\hline \multicolumn{5}{|l|}{ ASAROIDEAE } \\
\hline Saruma henryi Oliv. & + & ++ & facultative & \\
\hline Asarum canadense $\mathrm{L}$. & + & ++ & yes & \\
\hline \multicolumn{5}{|l|}{ ARISTOLOCHIOIDEAE } \\
\hline Thottea siliquosa (Lam.) Hou & + & + & no & \\
\hline \multicolumn{5}{|l|}{ Aristolochia L } \\
\hline \multicolumn{5}{|l|}{ subgenus Isotrema } \\
\hline A. serpentaria L. & + & +++ & facultative & \\
\hline A. macrophylla Lam. & ++ & + & facultative & \\
\hline A. californica Torr. & ++ & & no & \\
\hline A. tomentosa Sims & +++ & + & facultative & \\
\hline A. holostylis (Duchartre) F. Gonzalez & + & + & no & \\
\hline \multicolumn{5}{|l|}{ subgenus Pararistolochia } \\
\hline A. goldieana (Hook.f.) Hutch. \& Dalz & + & ++ & no & \\
\hline A. prevenosa F.Muell. & + & ++ & no & \\
\hline A. promissa (Mast.) Keay & + & ++ & no & \\
\hline A. triactina (Hook. f.) Hutch \& Dalz & + & ++ & no & \\
\hline \multicolumn{5}{|l|}{ subgenus Aristolochia } \\
\hline A. acuminata Lam. & ++ & ++ & no & \\
\hline A. anguicida Jacq. & ++ & ++ & no & \\
\hline A. clematitis L. & +++ & +++ & yes & \\
\hline A. elegans Mast. & ++ & ++ & no & ++ \\
\hline A. fimbriata Cham. & +++ & +++ & facultative & ++ \\
\hline A. gigantea Mart. \& Zucc. & + & + & no & \\
\hline A. grandiflora Sw. & + & + & no & \\
\hline A. passiflorafolia Rich. & + & + & no & \\
\hline A. ringens Vahl. & + & ++ & no & + \\
\hline A. trilobata L. & + & ++ & no & \\
\hline A. lindneri Berg. & + & + & no & \\
\hline A. maxima Jacq & + & ++ & no & \\
\hline Aristolochia sp. & + & ++ & no & \\
\hline
\end{tabular}

Observed presence of advantageous features indicated with plus sign. Observations were made either in the Biology Department greenhouse at Penn State University or at the Botanical Gardens of Dresden or Bonn.

1 after Petch [42].

experiments were conducted with A. elegans and A. fimbriata because of their small genomes, ease of culture, and prolific flowering (Figure 2, Table 2). Both species could be hand pollinated to accomplish cross- and selfpollination events using simple methods, as described in Additional file 2: Cultivation Supplement. Morphological changes in the perianth and gynostemium associated with maturation of the anthers and stigmatic surfaces are described for $A$. fimbriata from the day of anthesis (day 1) through day 3 (Additional file 2: Figure S1). Selfpollination in A. fimbriata was most effective on day 2, both in terms of fruit production and seed viability (Additional file 2: Figure S2, Additional file 2: Table S3). Using in vitro germination methods, $59 \%$ of seeds produced in open-air pollinations of $A$. fimbriata germinated normally, compared to $50 \%$ of seeds produced from self-pollination of day 2 flowers (Additional file 2: Table S3). Further details are provided in Additional file 2: Cultivation Supplement.

Agrobacterium tumefaciens-mediated genetic transformation experiments were performed with two varieties of A. fimbriata (NV, VL) and with Saruma henryi. The binary vector utilized [46] contained a neomycin phosphotransferase marker gene (NPTII) for antibiotic selection and an enhanced green fluorescent protein reporter gene (EGFP); both genes were under the control of the E12- $\Omega$ CaMV-35S promoter [46]. High frequency transient expression was observed in the leaf explants at 


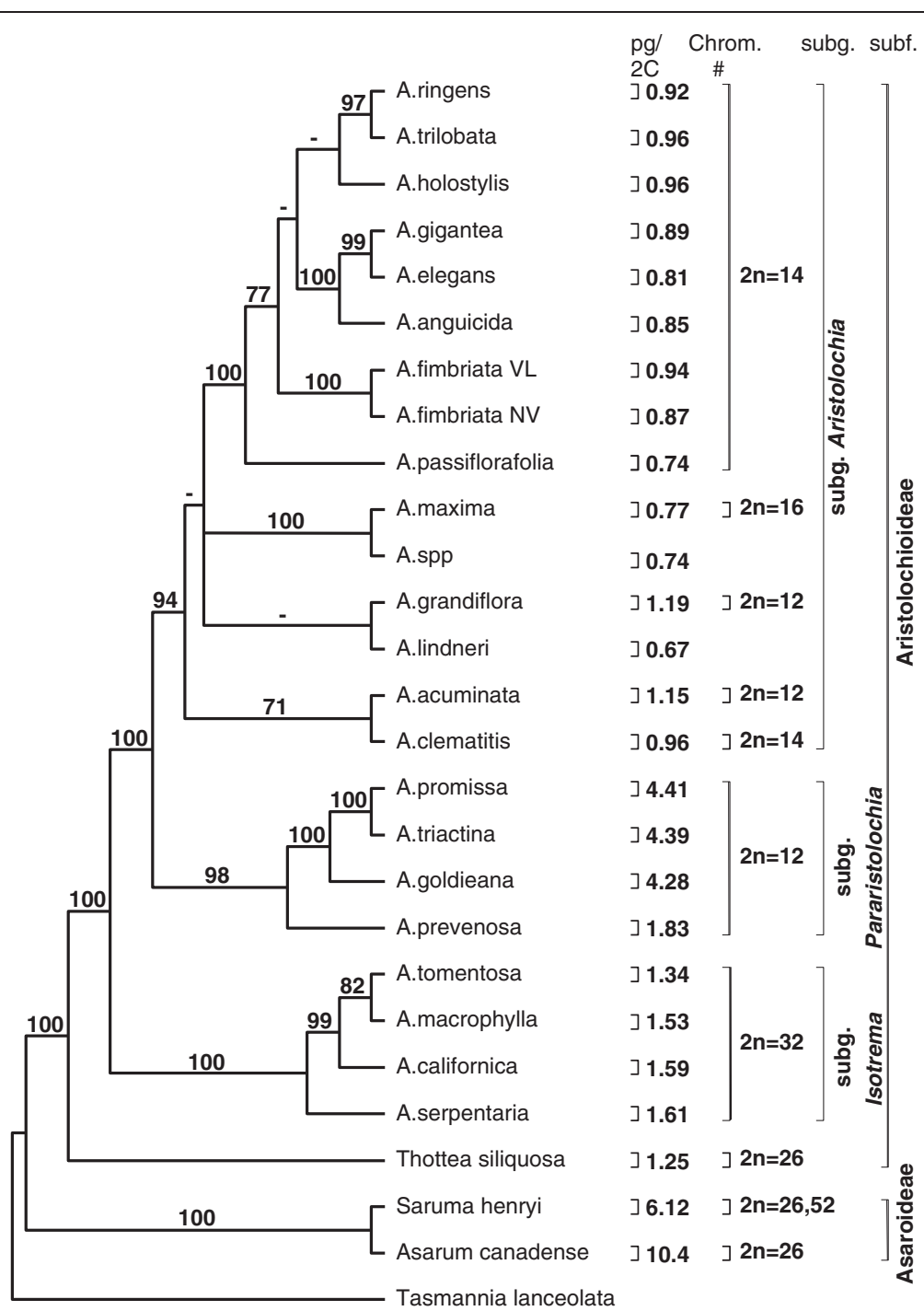

Figure 5 Phylogenetic relationships among sampled Aristolochiaceae, with Tasmannia lanceolata (Canellales) as outgroup. Maximum parsimony strict consensus tree with genome sizes $(\mathrm{Mbp} / 1 \mathrm{C})$ and chromosome counts indicated. If different genome sizes were obtained from different plants belonging to the same species, the smallest size was plotted on the tree. For range of genome sizes within one species and standard deviation refer to Table 4. Bootstrap values from 1000 replicates are indicated on the branches.

7 days after culture initiation (Figure 6A-D), followed by production of transgenic calli and shoot primordia at 24 days after culture initiation (Figure $6 \mathrm{E}$ and F). Stable transformation (evident 30 days after culture initiation) was observed in $40 \%$ of the $S$. henryi explants $(n=25)$, and in $58 \%$ of the A. fimbriata explants $(n=59)$. Additionally, transgenic calli, shoot, and root primordia (Figure 6G, 6H) were successfully regenerated from stem explants of $A$. fimbriata tissue cultured plants, with EGFP expression visible in a distinct subset of the regenerating tissues (Figure 6I and J). The integration of EGFP in the transgenic calli was confirmed by genomic PCR analysis (Figure 6K). The PCR reactions including DNA from green fluorescent calli (Figure 6K, lanes 3-5) resulted in the amplification of one $427 \mathrm{bp}$ fragment identical to the control reaction including plasmid pGH00.0131 DNA (Figure 6K, lane 7). Amplification was not detected in the control reaction containing DNA from non-transgenic Aristolochia leaf tissue (Figure 6K, lane 2) or in the control reaction without DNA (Figure 6K, lane 6).

\section{Physical and life cycle features of Aristolochia fimbriata}

We characterized the physical and life cycle features of Aristolochia fimbriata (Figure $4 \mathrm{H}$ ) to further assess its potential as a model system. Seeds planted in potting medium in the greenhouse germinated at rates up to $100 \%$, and flowered in as few as 62 days after planting. 

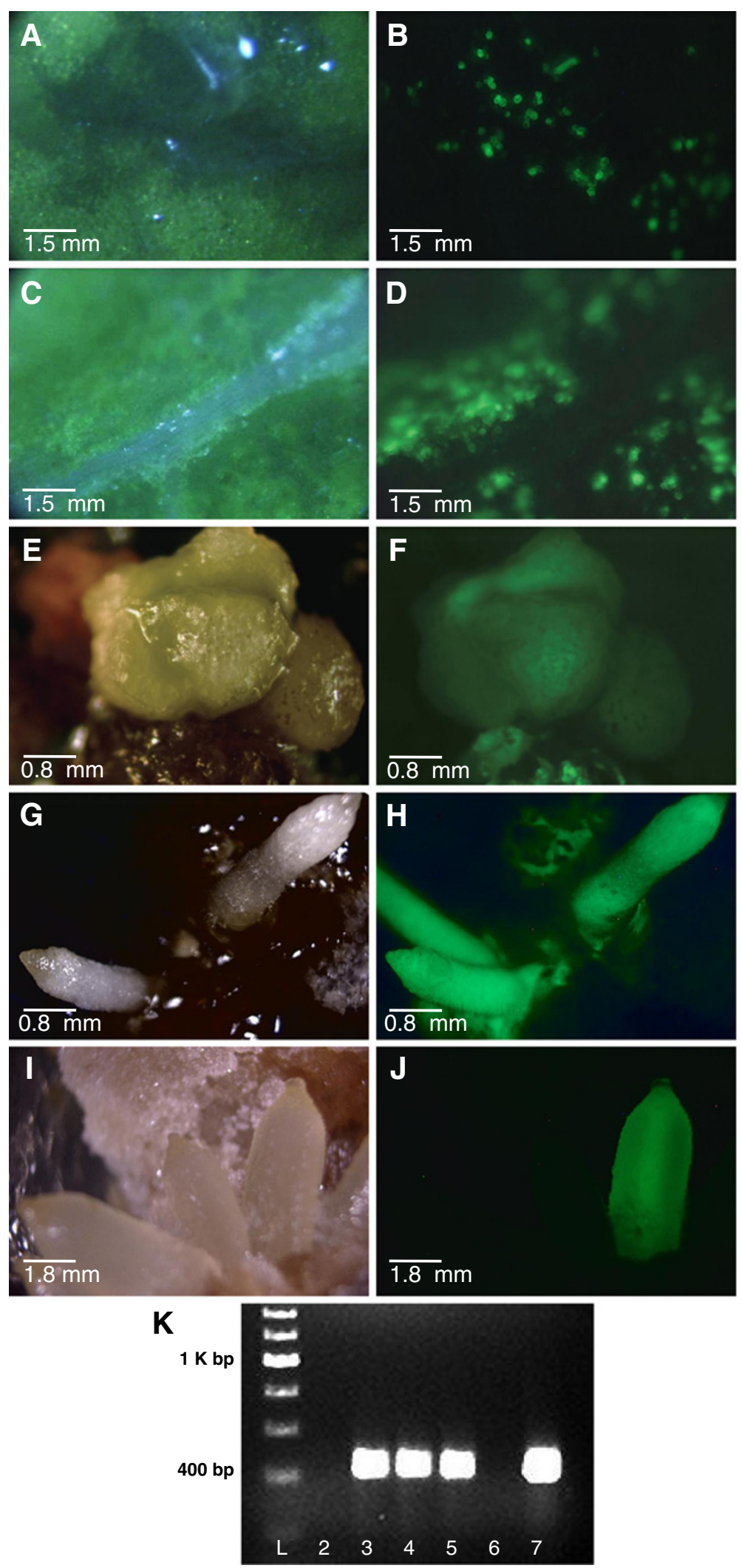

Figure 6 (See legend on next page.) 
(See figure on previous page.)

Figure 6 Green fluorescent protein expression in Aristolochiaceae. A, C, E, G, I . Light images. B, D, F, H, J. Fluorescent images. A-D. Leaf explants 10 days after Agrobacterium tumefaciens infection A, B. Saruma henryi C, D. A. fimbriata E, F. Regenerating A. fimbriata stem explant. G, H, I, J. Regenerating A. fimbriata roots (one root is shaded from light source in G). $\mathbf{K}$. Gel image of PCR products; Lane L- 200bp ladder, bright band at $1 \mathrm{~K}$ bp with corresponding bands at each 200bp; Lane 2- A. fimbriata (WT) DNA; Lane 3- In vitro transformed callus 1; Lane 4- In vitro transformed callus 2; Lane 5- In vitro transformed callus; Lane 6- Negative Control; Lane 7-Plasmid PC (1 ng/ul).

Cultivated as a small pot crop in the greenhouse, A. fimbriata stock plants occupy minimal bench space (Figure 7A), and were not particularly susceptible to any pest or pathogen, though commercial pesticide treatments were applied greenhouse-wide as needed. Vines are supported by a small trellis during periods of flowering or fruit ripening (Figure $7 \mathrm{~B}$ ) to prevent mechanical damage and facilitate fruit harvest. Plants flower copiously from axillary nodes on multiple indeterminate stems that arise from the tuberous underground organ. A new flower opens every two to three days along the stem (Figure 7C) facilitating collection of staged tissues. Fruits from open-air pollinations on one-year-old plants averaged over one hundred seeds per capsule. Seeds are heart-shaped and small $(\sim 5 \times 4 \times 1 \mathrm{~mm})$ and about 500 seeds can be stored in a $15-\mathrm{ml}$ tube.

Although seasonally green in its native habitat, A. fimbriata grows year round in greenhouse culture. It forms a large perenniating tuber that can be divided to produce clones. Stems can be pruned back to the tuber after fruit collection to support greenhouse sanitation efforts, or "as needed" to stimulate new growth. New stems generated in this way will flower in two weeks. Fruit size, leaf size, and number of seeds increase in older, larger plants.
The longevity of individual plants provides an ongoing source of seed from a single experimental subject.

We developed in vitro methods for germinating seeds to support collection of seedling tissues and for comparisons of seed viability. Light during germination is required for true leaves to emerge. Seeds germinated significantly better in wet toweling $($ mean $=61 \%)$ compared to germination on plates containing solid, sucrose-free media (mean=9\%). Light and age of seed (up to 2.5 years) had no significant effect on germination with $80 \%$ germinating by 70 days. More details are available in Additional file 2: Cultivation Supplement.

\section{A large database of expressed gene sequences}

The Ancestral Angiosperm Genome Project (http:// ancangio.uga.edu/) has selected Aristolochia fimbriata for deep EST sequencing using a combination of traditional capillary [35] and extensive next generation (454, Illumina) sequencing of libraries constructed from multiple vegetative and reproductive tissues and stages. There are currently 36,248 Sanger EST sequences available from $A$. fimbriata libraries made from RNA from pre-meiotic flower buds (15,759 sequences) and a mixed library from multiple vegetative tissues $(20,489$
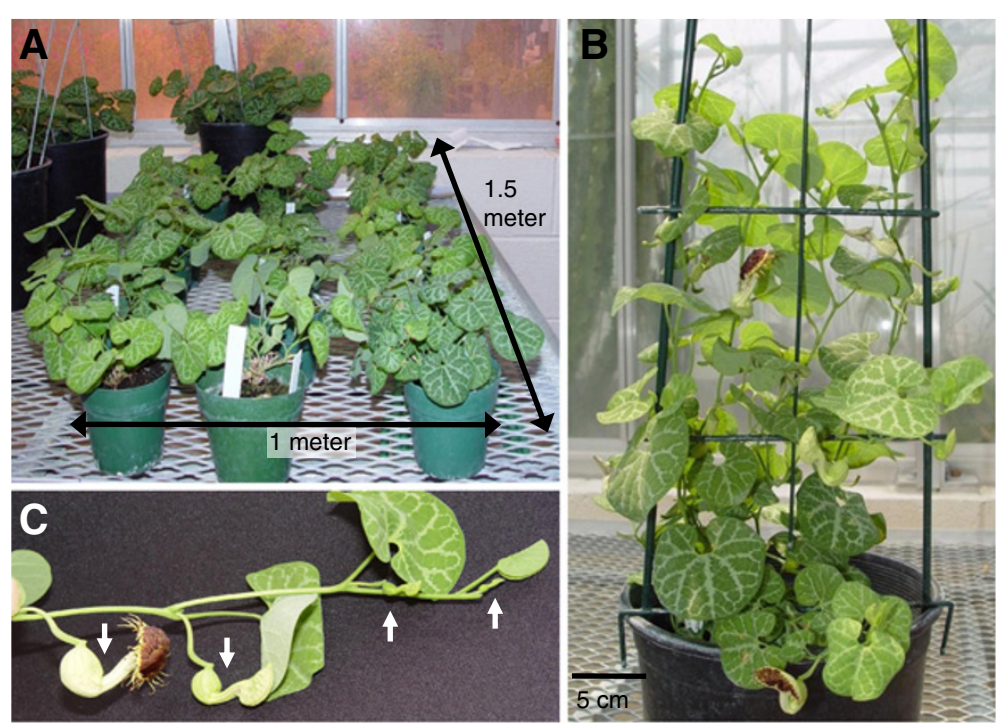

Figure 7 Aristolochia fimbriata. A. Twelve three-year old stock plants maintained in pots (12 cm diameter) occupy $1 \mathrm{~m} \times 1.5 \mathrm{~m}$ bench space in the greenhouse $\mathbf{B}$. Plants in use for genetic crosses, seed or tissue collection are trellised $\mathbf{C}$. Close-up of vine showing flowers and floral buds at successive developmental stages on one stem [with arrows]. 
sequences). Over 3.8 million 454FLX ESTs are available from eleven non-normalized libraries representing preand post-meiotic floral buds, open flowers, early and late stage seedlings, terminal/axial buds, roots, young and mature leaves, and early and late stage developing fruits. Sequences have been cleaned, assembled, and posted to searchable public databases (see Methods).

Although detailed results using the $A$. fimbriata EST sequences will be presented elsewhere, we have initially characterized the Aristolochiaceae EST database here using BLAST analyses as described in Albert et al. [35] to identify putative homologs of many interesting regulatory and signaling genes (see Table 3 for examples). Aristolochia cDNA sequences had greater sequence similarity with other monocot or eudicot species (e.g., Vitis, Poplar and Oryza) than with Arabidopsis, highlighting the important role $A$. fimbriata will play in rooting phylogenetic analyses of gene function (Table 3, and additional results not shown). Consistent with the composition of tissues included in the libraries, we found putative orthologs of many genes important for development such as auxin efflux carrier PIN1, phytochrome signaling protein GIGANTEA, as well as floral development regulators AP3, AINTEGUMENTA, and SEP3 (Table 3). Maximum likelihood analyses of two genes reported in Table 3 illustrate contributions of Aristolochia to the interpretation of gene family evolution in angiosperms. Orthologs for alpha-galactosidase (Additional file 3: Maximum likelihood analysis of orthologs for alphagalactosidase (ATAGAL1; AT5G08380)) identify an ancient gene duplication in a common ancestor of angiosperms (blue star). Orthologs for the MYB-domain protein AS1 in Arabidopsis, PHAN in Antirrhinum, and ROUGHSHEATH in maize (Additional file 4: Maximum likelihood analysis of orthologs for MYB-domain protein ASYMMETRIC LEAVES 1 (AS1; AT2G37630)) identify an ancient gene duplication in a common angiosperm ancestor (blue star) and a second gene duplication specific to $A$. fimbriata (green star).

\section{Discussion}

\section{Aristolochia fimbriata has many characteristics of a valuable experimental model}

A basal angiosperm experimental system is needed to analyze basal angiosperm gene functions and to test hypotheses about the evolution of developmental and biochemical pathways in flowering plants. The herbaceous basal angiosperm Saruma henryi was selected for deep EST sequencing by the Floral Genome Project [35] and was initially considered for development as a model genetic system, but the slow growth, need for vernalization, and low flower and fruit production of Saruma prompted a thorough investigation of all other basal angiosperms, with the specific aim to identify a species more amenable to genetic experimentation. After evaluating 29 basal angiosperm families, including in situ assessment of over 20 species in family Aristolochiaceae and in vitro transformation of two species, we found in Aristolochia fimbriata many of the features desired in a genetic experimental system. A. fimbriata has the physical features for large-scale greenhouse cultivation, including robust container growth, continuous flowering, and selfcompatibility, permitting the production of large numbers of homozygous individuals required for gene functional analysis in a single life cycle. We have begun to develop inbred lines to facilitate genome mapping and large scale mutagenesis experiments. High-efficiency transformation with a GFP construct allows rapid, nondestructive identification of transformed tissues for subsequent processing, and our in vitro micropropagation and regeneration methods can yield greenhouse acclimated plants in three months [47]. Individual A. fimbriata plants survive indefinitely, providing ongoing access to mutant lines that can be cloned for distribution to the research community. Currently available for analysis, the VL and NV genotypes possess a number of readily discernible traits including leaf variegation (Figure $8 \mathrm{~A}$ and $\mathrm{C}$ ) and perianth details (Figure 8B, D and E) amenable to investigation at the genetic level. Further inbreeding and crossbreeding of these and other genotypes can be used to dissect the genetic basis for phenotypic differences, yield useful markers, identify linked genes, and ultimately contribute to mapping and assembling the A. fimbriata genome sequence.

\section{Aristolochia fimbriata is well positioned for studies of the evolution of development}

Aristolochia fimbriata is in a strong phylogenetic position to support comparative and evolutionary studies. Aristolochiaceae, with its approximately 550 species in four genera [18], is one of the most diverse and speciose families among the basal angiosperms. The largest genus in the family, Aristolochia contains approximately 450 species, and has long been of interest to botanists due to its monosymmetric, unipartite insect-trapping perianth (Figure 8E) and an unusual gynostemium, which is a structure formed by the fusion of the gynoecium with the anthers. A. fimbriata is a typical member of the family, such that its flower was modelled in glass by Leopold and Rudolf Blaschka in the latter half of the nineteenth century [48]. A. fimbriata differs from closely related Aristolochia species in several late stage modifications (e.g., fimbriae, papillae, pubescence), and in well-documented aspects of perianth and gynostemium development [49,50]. These features are potentially suitable for molecular analysis and studies of gene function using an A. fimbriata experimental system.

Comparisons between closely related taxa in Aristolochiaceae could support discovery of differences responsible for inter- and intra-generic speciation and may 
Table 3 Orthologs of genes involved in development, cell wall biosynthesis, and stress response in A. fimbriata EST assemblies

\begin{tabular}{|c|c|c|c|c|c|}
\hline Annotation & ESTs & Length & Identity & Evalue & AGI \\
\hline \multicolumn{6}{|l|}{ Development } \\
\hline CLV2 protein kinase maintenance of stem cell populations (Vitis vinifera) Aristolochia|b3_Irc17313 & 69 & 1806 & $51 \%$ & $5 e-137$ & AT1G65380 \\
\hline GIGANTEA (Vitis vinifera) Aristolochia|b3_c14545 & 168 & 1770 & $58 \%$ & $9 e-157$ & AT1G22770 \\
\hline PIN1 auxin efflux carrier (Arabidopsis thaliana) Aristolochia|b3_Irc14465 & 123 & 1805 & $68 \%$ & 0 & AT1G73590 \\
\hline AINTEGUMENTA (Carica papaya) Aristolochia|b3_c20214 & 41 & 1991 & $84 \%$ & $2 \mathrm{e}-161$ & AT4G37750 \\
\hline ASYMMETRIC LEAVES 1 (AS1), homologous to maize RS1 (Vitis vinifera) Aristolochia|b3_c2263 & 119 & 1553 & $50 \%$ & $2 e-93$ & AT2G37630 \\
\hline SEP3 MADs box transcription factor (Vitis vinifera) Aristolochia|b3_c2250 & 108 & 1131 & $70 \%$ & $3 e-105$ & AT1G24260 \\
\hline $\begin{array}{l}\text { RNA Slicer that selectively recruits microRNAs and siRNAs (Arabidopsis thaliana) Aristolochial } \\
\text { b3_c16036 }\end{array}$ & 158 & 3157 & $82 \%$ & 0 & AT1G48410 \\
\hline NAC containing domain (Vitis vinifera) Aristolochia|b3_c613 & 521 & 1598 & $61 \%$ & $2 \mathrm{e}-135$ & AT5G61430 \\
\hline AP3/APETALA 3 DNA binding/transcription (Vitis vinifera) Aristolochia|b3_c14320 & 154 & 1084 & $46 \%$ & $6 e-67$ & AT3G54340 \\
\hline \multicolumn{6}{|l|}{ Cell wall biosynthesis } \\
\hline Cinnamoyl alchohol dehydrogenase, putative (Vitis vinifera) Aristolochia|b3_c675 & 405 & 1559 & $74 \%$ & $8 \mathrm{e}-168$ & AT1G72680 \\
\hline ATAGAL1 alpha-galactosidase similar to ATAGAL2 (Vitis vinifera) Aristolochia|b3_c1141 & 231 & 2016 & $73 \%$ & $2 \mathrm{e}-179$ & AT5G08380 \\
\hline Xyloglucan endotransglucosylase/hydrolase (XTH9) (Populus trichocarpa) Aristolochia|b3_Irc29524 & 21 & 783 & $77 \%$ & $7 e-45$ & AT4G03210 \\
\hline $\begin{array}{l}\text { EXPA10: expansin involved in the formation of nematode-induced syncytia in roots (Carica papaya) } \\
\text { Aristolochia|b3_c2232 }\end{array}$ & 340 & 1444 & $65 \%$ & $3 e-106$ & AT1G26770 \\
\hline \multicolumn{6}{|l|}{ Stress response } \\
\hline $\begin{array}{l}\text { BASIC CHITINASE in ethylene/jasmonic acid mediated signalling pathway during SAR (Populus } \\
\text { trichocarpa) Aristolochia|b3_c857 }\end{array}$ & 301 & 1486 & $60 \%$ & 1e -88 & AT3G12500 \\
\hline Zeaxanthin epoxidase gene (Arabidopsis thaliana) Aristolochia|b3_c15151 & 113 & 1864 & $70 \%$ & 0 & AT5G67030 \\
\hline $\begin{array}{l}\text { MAP KINASE } 3 \text { (MPK3) upregulated in response to touch, cold, salinity, chitin (Carica papaya) } \\
\text { Aristolochia|b3_c14569 }\end{array}$ & 185 & 1655 & $78 \%$ & 0 & AT3G45640 \\
\hline $\begin{array}{l}\text { POM-POM1; Chitinase-like protein essential for tolerance to heat, salt, drought stresses (Vitis vinifera) } \\
\text { Aristolochia|b3_c843 }\end{array}$ & 723 & 1465 & $72 \%$ & $1 e-134$ & AT1G05850 \\
\hline Salt tolerance protein (STO) (Populus trichocarpa) Aristolochia|b3_c701 & 348 & 1661 & $52 \%$ & $1 \mathrm{e}-171$ & AT1G06040 \\
\hline $\begin{array}{l}\text { RAR1 disease resistance protein; Required for R protein accumulation (Carica papaya) Aristolochial } \\
\text { b3_c23 }\end{array}$ & 694 & 1245 & $64 \%$ & $5 e-93$ & AT5G51700 \\
\hline
\end{tabular}

All assembled unigenes (http://ancangio.uga.edu/) were searched (blastx) against the sequenced plant genomes of Arabidopsis thaliana, Oryza sativa, Populus trichocarpa, Vitis vinifera, Carica papaya, Medicago truncatula, and Sorghum bicolor (http://www.floralgenome.org/tribedb/index.pl). Values reported are the number of ESTs comprising each unigene, the unigene length (bp), percent amino acid identity of the best blastx hit, e-value, Arabidopsis AGl, and the annotation of the best Arabidopsis hit as well as the species with the best overall hit following (in parentheses) and the Aristolochia unigene number.

resolve long-standing questions about the origins of floral structures. Unlike the species-rich genus Aristolochia, the three other genera in the family (Saruma (Figure 4A), Asarum (Figure 4B), and Thottea (Figure 4 C)) have radially symmetric perianths, and account for approximately 100 species (Table 1). The bilaterally symmetric perianth of Aristolochia represents the most "basal" occurrence of this important floral adaptation in angiosperms. A. fimbriata presents the opportunity to investigate the genetic basis of bilateral symmetry in magnoliids and compare it with that found in the eudicot models Antirrhinum [51] and Lotus [52]. Existing microscopic studies of anatomy and development in Aristolochiaceae will facilitate comparative and functional studies, and provide insight into the evolution of development in this family. For Saruma the anatomy of stem, leaf, flower, and pollen have been described [53,54], and across Aristolochiaceae, ovule and seed development
[55], microsporogenesis [56], female gametophyte evolution [15,57], and inflorescence morphology [58] have been described in detail.

Morphological and gene expression studies indicate Aristolochiaceae offers an excellent system in which to study the role of homologs of B-class MADS-box genes, which are required for the organ identities of petal and stamen in higher eudicots and putative homologous organs in grasses $[28,59]$. The flower of the monotypic genus Saruma (Figure 4B) with its apparent sepals, petals, stamens, and carpels resembles that of the typical magnoliid flower more than any other species in the family. Putative homologs of B-class genes $(A P 3, P I)$ are expressed in the stamens of Saruma and in its petaloid whorl which is of staminoid origin [60]. Putative AP3 homologs have been found in Thottea and Asarum $[61,62]$, and are expected to be expressed in the stamens and appendages opposite the sepals (which have been 

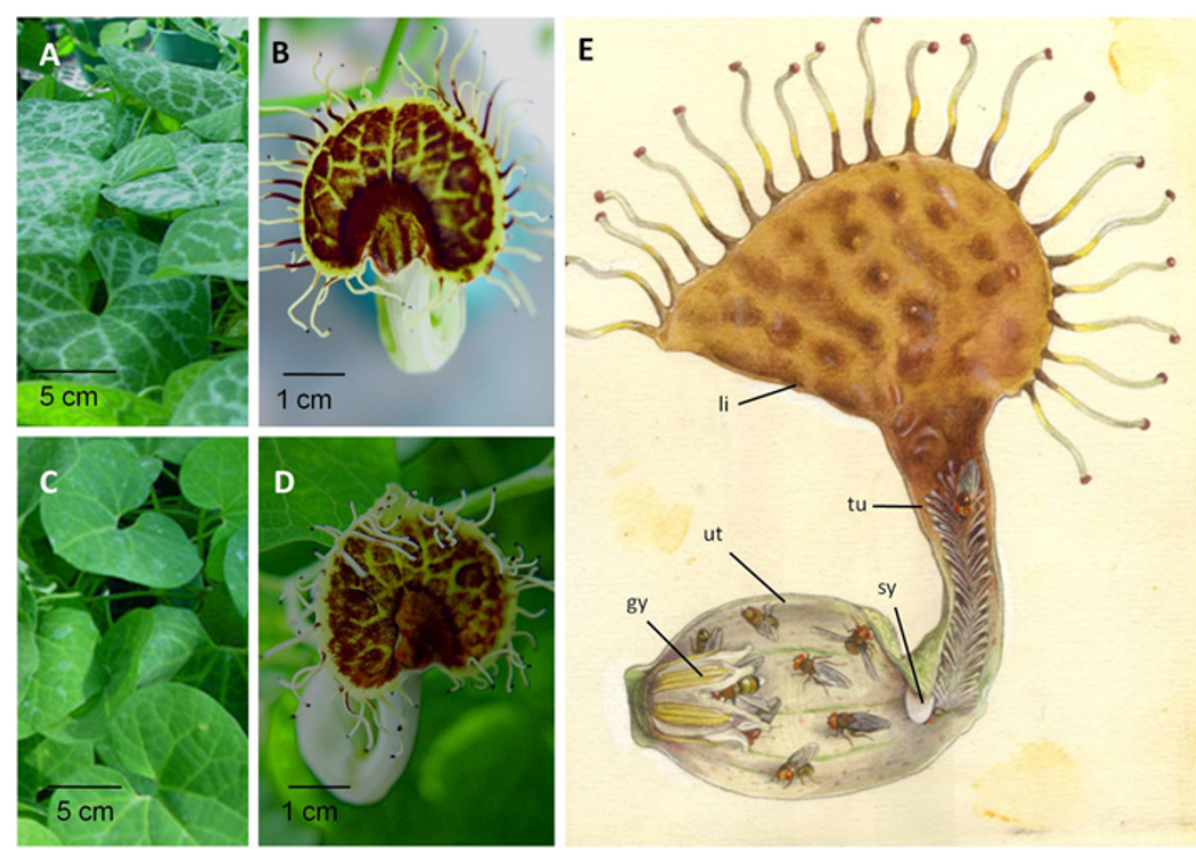

Figure 8 Aristolochia fimbriata genotype and perianth detail. A, B. VL genotype C, D. NV genotype A, C. Presence, absence of leaf variegation B, D. Perianth varies in shape and color E. Perianth is highly modified for insect pollination. Modifications include limb (li), tube (tu), syrinx (sy), utricle (ut) and gynostemium (gy), which has stamen locules on the outside and interior stigmatic surfaces. Glass model by Leopold and Rudolph Blatschka made near Dresden, Germany illustrated by Fritz Kredel (reproduced with permission).

interpreted to be petaloid) in those genera [49,50,63-66]. In Aristolochia, putative B-gene homologs are expressed in the stamens, and also in the innermost, specialized cells of the outermost (and only) perianth whorl [67] which has been interpreted as a calyx [49,67]. Although the expression of putative homologs of the B-class genes in Saruma and Aristolochia [67] suggests they do not regulate perianth form by determining typical floral organ identity, expression is consistently found in pollinatorattracting structures of the flower. Homologs of B-class genes might regulate other aspects of perianth development and might not be required at all for perianth identity in Aristolochiaceae. Experimental evidence from Aristolochiaceae is needed to determine what role B-class homologs play in basal angiosperm floral development, particularly since the expression patterns of these genes in the first perianth whorl of other basal taxa is variable $[61,68,69]$. Gene function in Aristolochiaceae can be investigated in A. fimbriata using sequences from Aristolochia and three other genera in the family.

\section{Aristolochia contains highly developed biochemical pathways offering insight into evolution of biochemical synthesis and coevolution with insects}

Aristolochiaceae produce a complex mixture of secondary metabolites, as is common in basal angiosperms. In particular, aristolochic acids and aristolactams are produced in Aristolochiaceae and are found throughout Piperales and the basal eudicots (reviewed in [70]). Compounds produced by alkaloid biosynthesis pathways in the poppy family (Papaveraceae, Ranunculales) are of great pharmacological importance, and it is a parallel pathway in Aristolochiaceae that yields aristolochic acids and aristolactams which are important for public health. Over 680 reports of traditional pharmacological use of about 100 species of Aristolochia have been compiled in a review [71]. The common name "birthwort" attributed to Aristolochia refers to traditional use of some species, particularly extracts from root tissues, as abortifacients, emmenagogues, or post-coital antifertility agents [72]. More recently, constituents of primarily root extracts from Aristolochia species have been isolated and evaluated for biological activity as antibiotics, antivenoms and tumor-inhibiting agents [73-80], although aristolochic acids become bioactivated and carcinogenic when ingested $[81,82]$.

In addition to its pharmacological properties, Aristolochia provides an opportunity to explore coevolution of secondary metabolites with insects. Dipterans commonly serve as pollinators in Aristolochia [42,83-87], sometimes having specialized, mutualistic relationships involving egg deposition in the flowers [88-91]. Dipteran pollinators are thought to be attracted to secondary metabolites mimicking the aroma of a food source [42,91], or acting as pheromones to attract species-specific, sex-specific pollinators [92], or stimulating oviposition [89]. 
Aristolochia species are also important host plants for the larval stages of swallowtail butterflies (Papilionidae, Lepidoptera) [93-98]. Secondary metabolites found in particular Aristolochia species are critical for the defense and survival of associated swallowtail butterfly species during their feeding stage, such that the decline of butterfly populations is attributed to decreased distributions of particular Aristolochia species [99]. Finally, secondary metabolites of Aristolochia and related species are of interest for their repellent, insecticidal, and antifeedant activities in herbivorous plant pests [100-102]. Biochemistry in Aristolochia can be evaluated in greenhouse grown or micropropagated plants, using chemical analyses (e.g., mass spectroscopy, gas chromatography) to further characterize constituents of specific plant tissues in A. fimbriata. Biochemical pathways can be further investigated using transformed roots or callus (Figure 6G, H, I and J) currently available in the transformation-regeneration system, without further optimization.

\section{Aristolochia can provide insight into development of woodiness}

Woodiness is an important seed plant feature, both for commercial and ecological purposes [9]. Growth forms within the Aristolochiaceae vary widely, presenting an opportunity to investigate growth form traits including flexibility, stiffness, and woodiness of closely related species [103]. Aristolochiaceae are most commonly perennial, self-supporting herbs (Figure 4A, B), procumbent or trailing, non-self-supporting vines (A. passiflorafolia, A. fimbriata) (Figure 4G, H), and woody lianas (Figure $4 \mathrm{~F}$ ). Rarely, they are small woody shrubs (Figure 4C); and even more rarely trees (or tree-like forms) (Figure 4D). Early diverging members of the family (Asarum and Saruma) are characterized as perennial rhizomatous herbs, and the sister group to Aristolochia is comprised of the woody sub-shrub Thottea (Figure 4C). Perennial herbs appeared iteratively in the topology (Figure 5) of the family phylogeny and are nested within groups of woody vines. Most eudicots and monocots are modular organisms with indeterminate body plans. Shifts in the ontogenetic trajectory may be expected to have a profound effect on the overall size and potential life history of the descendant. This effect might have played a key role in growth form evolution and the development of flexibility, stiffness, and woodiness in Aristolochiaceae [103-105]. Differences in these growth form traits can be investigated in Aristolochia species of interest, including A. fimbriata, beginning with cellular level observations and descriptions of development of secondary growth ("wood"). Molecular and cell biological methods can be used to locate and describe in Aristolochia homologs of genes involved in growth form traits in other species (e.g., Arabidopsis, Populus, Liriodendron), to further characterize the role of interesting gene products in Aristolochiaceae.

\section{Aristolochia might reveal features of the ancestor common to monocots and eudicots}

Aristolochiaceae occurs in Piperales, in the magnoliid clade, which is the most species-rich basal angiosperm clade and sister to the very large and diverse monocot plus eudicot clades [7-9]. As such, Aristolochia can provide a close outgroup for analysis of ancestral traits in the major groups of angiosperms. The ancient features of different lineages in Piperales have long been recognized, earning them classification as "paleoherbs" in early works [106,107]. In addition to being less woody than other basal angiosperm families, Aristolochiaceae and close relatives show a mixture of features of monocots and eudicots. Traits shared with eudicots include seedlings with two cotyledons and secondary growth from a vascular cambium. The more ancestral clade, Asaroideae, is comprised of rhizomatous perennials similar to basal monocots and eudicots. Also found in Piperales are aquatics (i.e., Saururaceae), a common adaptation also found in both basal eudicots and monocots (e.g. Ranunculales, Acorales, Alismatales). Piperales, and Aristolochiaceae in particular, displays other features more commonly associated with monocots, including trimerous flowers, median prophylls (which are shared with nearly all monocots and only few eudicot clades), and subtype PII sieve-tube plastids [108,109]. Piperales also share distichous placement of leaves and palmate leaf venation with early diverging monocots (Alismatales, Arales). Indeed, in some phylogenies, Piperales appear as the closest relative to Acorus, the sister of all other monocots [110]. Consequently, many features in monocots and eudicots, both genetic and phenotypic, can be expected to have a homolog in Aristolochiaceae and its relatives, and would help to characterize the extinct ancestors of the eudicot, monocot and magnoliid clades.

\section{Growing genomic resources in Aristolochiaceae support further development of a model system}

Genomic resources are growing rapidly for Aristolochiaceae, which will facilitate the identification and study of genes, gene families, and gene functions. Presently, over 3.8 million sequence reads from 13 diverse libraries are publicly available for Aristolochia fimbriata that provide a deep sampling of expressed gene sequences in this species. We anticipate these cDNA sequences, and others being currently generated, will contribute to new and ongoing studies of evolution of development in and comparative genomics with Aristolochia. Comparative analyses of cDNA sequences within Aristolochiaceae will be facilitated as well by 10,274 EST sequences from Saruma 
henryi (Figure 4B). Saruma was selected by the Floral Genome Project (FGP) to represent Aristolochiaceae for floral transcriptome sequencing (http://www.floralgenome. org/taxa/) because it appears to display ancestral morphological characters in the family $[53,111,112]$ and because its flower includes all four (sepal, petal, stamen, and carpel) floral whorls.

In addition to EST sequencing, two ongoing efforts have isolated micro RNAs (miRNAs) and other small RNAs from A. fimbriata. MiRNAs are small RNAs (21 nt) that play a major role as regulators of gene expression in various physiological, cellular, but, mainly developmental processes [113]. A fimbriata was selected as one of four basal angiosperms for small RNA sequencing using SBS/Illumina technology (http://smallrna.udel.edu/ index.php). Our lab has used cloning and capillary sequencing as well as 454 pyrosequencing to sequence miRNAs ([114], unpublished data). This study allowed the isolation of hundreds of different miRNA sequences belonging to 32 conserved families as well as several non-conserved families. Several potential miRNA targets were found in cDNA sequences of $A$. fimbriata. Predicted target genes include transcription factors but also genes implicated in various metabolic processes and in stress defense. The isolation of miRNAs from Aristolochia presents a good opportunity for analyzing the function of miRNAs in basal angiosperms and for understanding how miRNA-mediated regulation of gene expression has evolved in land plants by comparing miRNAs in basal angiosperms to those in basal eudicots and lower land plants $[115,116]$.

This core of genetic, genomic, and methodological resources is presently available as a foundation for further development of Aristolochia fimbriata as a basal angiosperm model system as well as for immediate use by the scientific community working on various areas of research including evolution of development, plant resistance to biotic and abiotic stresses, gene functional analysis, and comparative genomics.

\section{Conclusion}

We have used a rigorous process to select and develop resources for the basal angiosperm, A. fimbriata. Culturing and hand pollination methods required for rapid generation of homozygous lines needed for genetic experiments are described. The small genome size and immediate availability of sequence data supports future studies of molecular genetics and evolution. Hypotheses about gene evolution and gene function can be tested using a reverse genetic approach, i.e., over and under expression studies in a transformable species suitable for large-scale cultivation. The transformation system we present supports experimental investigation of secondary metabolites, compounds for which Aristolochia and other basal angiosperms are well known and which have long been of interest for their pharmacologic properties and for their roles in the co-evolution of animals with plants. Optimizing the selection phase for transformed A. fimbriata explants would facilitate a high throughput transformation system for investigating gene function and evolution in a basal angiosperm. The development of virally-induced gene silencing (VIGS, [117]) would provide another valuable tool for functional analysis in Aristolochia fimbriata. Along with continued development of genetic tools and genomic resources, A. fimbriata has the potential to become an excellent experimental system to provide further insight into the developmental, structural, and biochemical diversity found among basal angiosperms.

\section{Methods}

\section{Cultivation}

We evaluated 24 species of Aristolochiaceae. These were selected to encompass the phenotypic plasticity of the four-whorled, actinomorphic, Saruma, the actinomorphic, single-whorled perianths of Asarum and Thottea, and the bilaterally symmetric, highly modified and diverse flowers of Aristolochia. The sampled taxa also reflected the genetic diversity of the whole family recovered by phylogenetic analysis. Plant material was obtained from commercial nurseries, private donations, and academic sources. Vouchers of specimens included in the phylogenetic analysis and sampled for genome sizes have been entered into herbaria as described in Table 4. For these species, we evaluated evolution of genome size and chromosome number in a phylogenetic context. For 14 species of Aristolochia we evaluated life cycle and cultivation characteristics. Plants were maintained in the Biology Department greenhouse at The Pennsylvania State University, University Park, PA. All seeds were germinated in soil-free potting medium (ProMix BX, Premier Horticulture Inc., Quakertown, PA) in shallow germination trays with drainage holes, in the greenhouse at $18-27^{\circ} \mathrm{C}$ (varying from night to day) and $40-70 \%$ humidity. The trays were incubated on heating mats operating at approximately $27^{\circ} \mathrm{C}$, as needed. Natural day length was supplemented with high-pressure sodium lamps (1000 watt) October through April to provide twelve-hour days. Plants received regular watering as needed. Depending on the stage of growth, regular fertilizer applications were provided, as a drench, alternating Peter's Professional 15-16-17 Peat Lite Special at 200 PPM nitrogen (once to twice weekly) with Peters Professional 21-7-7 Acid Special (Scotts Horticulture, Marysville, OH) at 200 PPM nitrogen (approximately every six weeks). The plants were drenched once a month with 100 ppm chelated iron (Sprint 330 10\% iron, RoseCare.com, Santa Barbara, CA). 
Table 4 Genome sizes, vouchers, sources, and accessions for sequence data used

\begin{tabular}{|c|c|c|c|c|c|c|}
\hline Taxon & $\begin{array}{c}\text { Genome size } \\
(\mathrm{pg} / 2 \mathrm{C})+/ \text {-std. dev. }(\mathrm{n}=4)\end{array}$ & Std. & $\begin{array}{c}\text { DNA content of } \\
\text { sample species }(\mathrm{Mbp} / 1 \mathrm{C})\end{array}$ & $\begin{array}{c}\text { Voucher, } \\
\text { herbarium }\end{array}$ & Source & $\begin{array}{r}\text { GenBank } \\
\text { Accession }\end{array}$ \\
\hline \multirow[t]{2}{*}{$\begin{array}{l}\text { Aristolochia } \\
\text { acuminata Lam. }\end{array}$} & $1.15+/-0.007$ & $\mathrm{~s}$ & 564 & $\begin{array}{l}\text { BJB06.06A, } \\
\text { PAC }\end{array}$ & Victor Wong (private coll.) & \\
\hline & & & & $\begin{array}{c}\text { Wanke \& } \\
\text { Neinhuis } 146 \\
\text { DR }\end{array}$ & BG Dresden & DQ532063 \\
\hline \multirow{3}{*}{$\begin{array}{l}\text { Aristolochia } \\
\text { anguicida Jacq. }\end{array}$} & $0.81+/-0.005$ & S & 397 & \multirow{2}{*}{$\begin{array}{l}\text { BJB06.03A, } \\
\text { PAC }\end{array}$} & \multirow[t]{2}{*}{ Mario Blanco (private coll.) } & \\
\hline & $0.89+/-0.011$ & & 436 & & & \\
\hline & & & & $\begin{array}{l}\text { Wanke \& } \\
\text { Neinhuis s.n., } \\
\text { DR }\end{array}$ & BG Bonn & \\
\hline \multirow{3}{*}{$\begin{array}{l}\text { Aristolochia } \\
\text { californica Torr. }\end{array}$} & $1.58+/-0.006$ & $\mathrm{~s}$ & 774 & \multirow{2}{*}{$\begin{array}{l}\text { BJB05.02A, } \\
\text { PAC }\end{array}$} & \multirow[t]{2}{*}{ Albert J. Hill (private coll.) } & \\
\hline & $1.59+/-0.011$ & $\mathrm{R}$ & 779 & & & \\
\hline & & & & $\begin{array}{l}\text { Wanke \& } \\
\text { Neinhuis } 143 \\
\text { DR }\end{array}$ & BG Dresden & DQ532039 \\
\hline \multirow{5}{*}{$\begin{array}{l}\text { Aristolochia } \\
\text { clematitis L. }\end{array}$} & $0.96+/-0.001$ & \multirow[t]{2}{*}{$\mathrm{S}$} & 470 & \multirow{2}{*}{$\begin{array}{l}\text { BJB03.07A, } \\
\text { PAC }\end{array}$} & \multirow[t]{2}{*}{ Seneca Hill Perennials, NY } & \\
\hline & $0.99+/-0.001$ & & 485 & & & \\
\hline & $0.90+/-0.012$ & \multirow[t]{2}{*}{ S } & 441 & \multirow{2}{*}{$\begin{array}{l}\text { BJB03.03A, } \\
\text { PAC }\end{array}$} & \multirow[t]{2}{*}{ BG University Ulm } & \\
\hline & $0.98+/-0.008$ & & 480 & & & \\
\hline & & & & $\begin{array}{l}\text { W. Stahmüller, } \\
\mathrm{KL}\end{array}$ & Croatia, Is. Ilovik/Asinello & DQ296651 \\
\hline \multirow{2}{*}{$\begin{array}{l}\text { Aristolochia elegans } \\
\text { Mast. }\end{array}$} & $0.81+/-0.007$ & \multirow[t]{2}{*}{$\mathrm{S}$} & 397 & \multirow{2}{*}{$\begin{array}{l}\text { BJB03.02A, } \\
\text { PAC }\end{array}$} & \multirow[t]{2}{*}{ Park Seed Company, cat. \#0179-7 } & \\
\hline & $0.81+/-0.004$ & & 397 & & & \\
\hline \multirow{5}{*}{$\begin{array}{l}\text { Aristolochia } \\
\text { fimbriata Cham. }\end{array}$} & $0.91+/-0.004$ & \multirow[t]{2}{*}{$S$} & 446 & \multirow{2}{*}{$\begin{array}{l}\text { BJB03.04A, } \\
\text { PAC }\end{array}$} & \multirow[t]{2}{*}{ Larry D. Rosen ("VL") (private coll.) } & \\
\hline & $0.97+/-0.004$ & & 475 & & & \\
\hline & $0.96+/-0.001$ & S & 470 & $\begin{array}{l}\text { BJB03.05A, } \\
\text { PAC }\end{array}$ & Russ Strover ("VL") (private coll.) & \\
\hline & $0.84+/-0.009$ & \multirow[t]{2}{*}{$S$} & 412 & \multirow{2}{*}{$\begin{array}{l}\text { BJB04.08A, } \\
\text { PAC }\end{array}$} & \multirow{2}{*}{$\begin{array}{c}\text { Jardim Botanico, Departamento de } \\
\text { Botanica, ("NV"), Universidade de } \\
\text { Coimbra }\end{array}$} & \\
\hline & $0.89+/-0.004$ & & 436 & & & \\
\hline \multirow{2}{*}{$\begin{array}{l}\text { Aristolochia } \\
\text { gigantea Mart. \& } \\
\text { Zucc. }\end{array}$} & $0.89+/-0.013$ & \multirow[t]{2}{*}{ S } & 436 & \multirow{2}{*}{$\begin{array}{l}\text { BJB03.01A, } \\
\text { PAC }\end{array}$} & \multirow[t]{2}{*}{ Kartuz Greenhouses, CA } & JX485569 \\
\hline & $0.88+/-0.009$ & & 431 & & & \\
\hline Aristolochia & $1.19+/-0.009$ & $S$ & 583 & BJB03.02A, & Mario Blanco (private coll.) & \\
\hline & $1.20+/-0.006$ & & 588 & & & \\
\hline & $1.17+/-0.008$ & & 573 & & & \\
\hline & $1.21+/-0.012$ & & 593 & & & \\
\hline & $1.13+/-0.012$ & & 554 & & & \\
\hline & $1.26+/-0.006$ & & 617 & & & \\
\hline & $1.20+/-0.006$ & $\mathrm{R}$ & 588 & & & \\
\hline & & & & $\begin{array}{c}\text { Wanke \& } \\
\text { Neinhuis s.n., } \\
\text { DR }\end{array}$ & BG Dresden & DQ532052 \\
\hline $\begin{array}{l}\text { Aristolochia } \\
\text { goldieana (Hook.f.) } \\
\text { Hutch. \& Dalz. }\end{array}$ & $4.28+/-0.113$ & S & 2097 & $\begin{array}{l}\text { Neinhuis 117, } \\
\text { DR }\end{array}$ & BG Dresden & \\
\hline $\begin{array}{l}\text { Aristolochia } \\
\text { holostylis } \\
\text { (Duchartre) F. } \\
\text { Gonzalez }\end{array}$ & $0.96+/-0.029$ & S & 470 & $\begin{array}{l}\text { Neinhuis 116, } \\
\text { DR }\end{array}$ & BG Dresden & DQ532057 \\
\hline
\end{tabular}


Table 4 Genome sizes, vouchers, sources, and accessions for sequence data used (Continued)

\begin{tabular}{|c|c|c|c|c|c|c|}
\hline $\begin{array}{l}\text { Aristolochia lindneri } \\
\text { Berg. }\end{array}$ & $0.67+/-0.018$ & $S$ & 328 & $\begin{array}{l}\text { Neinhuis s.n., } \\
\text { DR }\end{array}$ & $\begin{array}{l}\text { BG Dresden, Bolivia, San Jose de } \\
\text { Chiquitos }\end{array}$ & DQ532047 \\
\hline \multirow{5}{*}{$\begin{array}{l}\text { Aristolochia } \\
\text { macrophylla Lam. }\end{array}$} & $1.54+/-0.011$ & \multirow[t]{2}{*}{$\mathrm{S}$} & 755 & \multirow{4}{*}{$\begin{array}{l}\text { BJB04.07A, } \\
\text { PAC }\end{array}$} & \multirow[t]{4}{*}{ Dawes Arboretum, OH } & \\
\hline & $1.53+/-0.033$ & & 750 & & & \\
\hline & $1.52+/-0.025$ & $\mathrm{R}$ & 745 & & & \\
\hline & $1.52+/-0.018$ & & 745 & & & \\
\hline & & & & $\begin{array}{l}\text { Neinhuis s.n., } \\
\text { DR }\end{array}$ & BG Dresden & DQ882193 \\
\hline \multirow{3}{*}{$\begin{array}{l}\text { Aristolochia maxima } \\
\text { Jaca }\end{array}$} & $0.77+/-0.009$ & $\mathrm{~s}$ & 755 & \multirow{2}{*}{$\begin{array}{l}\text { N.Pabon-Mora } \\
\text { \& F. Gonzalez, } \\
\text { NY }\end{array}$} & \multirow[t]{2}{*}{ NYBG } & \\
\hline & $0.78+/-0.017$ & $\mathrm{R}$ & 764 & & & \\
\hline & & & & $\begin{array}{l}\text { Gonzalez } \\
4018, \mathrm{COL}\end{array}$ & Panama, Panama & DQ532049 \\
\hline Aristolochia. sp. & $0.74+/-0.017$ & $\mathrm{~S}$ & 363 & $\begin{array}{c}\text { Wanke \& } \\
\text { Neinhuis s.n., } \\
\text { DR }\end{array}$ & BG Munich & \\
\hline \multirow[t]{2}{*}{$\begin{array}{l}\text { Aristolochia } \\
\text { passiflorafolia Rich. }\end{array}$} & $0.74+/-0.006$ & $\mathrm{~S}$ & 363 & $\begin{array}{l}\text { BJB06.05A, } \\
\text { PAC }\end{array}$ & Mario Blanco (private coll.) & \\
\hline & & & & $\begin{array}{l}\text { Neinhuis s.n., } \\
\text { DR }\end{array}$ & Cuba, BG Dresden & \\
\hline $\begin{array}{l}\text { Aristolochia } \\
\text { prevenosa F.Muell. }\end{array}$ & $1.83+/-0.006$ & $\mathrm{~s}$ & 1793 & $\begin{array}{c}\text { Neinhuis \& } \\
\text { Wanke s.n., DR }\end{array}$ & $\begin{array}{l}\text { BG Dresden, Queensland, Australia, } \\
\text { BG Dresden }\end{array}$ & \\
\hline $\begin{array}{l}\text { Aristolochia } \\
\text { promissa (Mast.) } \\
\text { Keay }\end{array}$ & $4.41+/-0.013$ & $S$ & 4321 & $\begin{array}{c}\text { Neinhuis } 118, \\
\text { DR }\end{array}$ & BG Dresden & DQ532065 \\
\hline \multirow{2}{*}{$\begin{array}{l}\text { Aristolochia ringens } \\
\text { Vahl. }\end{array}$} & $0.93+/-0.004$ & \multirow[t]{2}{*}{$\mathrm{s}$} & 456 & \multirow{2}{*}{$\begin{array}{l}\text { BJB06.07A, } \\
\text { PAC }\end{array}$} & \multirow[t]{2}{*}{ Mario Blanco (private coll.) } & \multirow[t]{2}{*}{ DQ532055 } \\
\hline & $0.91+/-0.003$ & & 446 & & & \\
\hline \multirow{7}{*}{$\begin{array}{l}\text { Aristolochia } \\
\text { serpentaria L. }\end{array}$} & $1.69+/-0.024$ & \multirow[t]{2}{*}{$\mathrm{s}$} & 828 & \multirow{2}{*}{$\begin{array}{l}\text { BJB03.03A, } \\
\text { PAC }\end{array}$} & \multirow[t]{2}{*}{ Larry D. Rosen (private coll.) } & \\
\hline & $1.67+/-0.019$ & & 818 & & & \\
\hline & $1.57+/-0.018$ & \multirow[t]{2}{*}{$S$} & 769 & \multirow{4}{*}{$\begin{array}{l}\text { BJB05.01A, } \\
\text { PAC }\end{array}$} & \multirow[t]{4}{*}{ B\&T World Seeds } & \\
\hline & $1.56+/-0.013$ & & 764 & & & \\
\hline & $1.61+/-0.035$ & $\mathrm{R}$ & 789 & & & \\
\hline & $1.58+/-0.008$ & & 774 & & & \\
\hline & & & & $\begin{array}{l}\text { Priv. coll. B. } \\
\text { Westlund }\end{array}$ & USA, Texas, Travis Co. & DQ532038 \\
\hline \multirow{5}{*}{$\begin{array}{l}\text { Aristolochia } \\
\text { tomentosa Sims }\end{array}$} & $1.13+/-0.008$ & \multirow[t]{2}{*}{$\mathrm{s}$} & 554 & \multirow{2}{*}{$\begin{array}{l}\text { BJB03.06A, } \\
\text { PAC }\end{array}$} & \multirow[t]{2}{*}{ Seneca Hill Perennials, NY } & \\
\hline & $1.39+/-0.010$ & & 681 & & & \\
\hline & $1.40+/-0.022$ & $S$ & 686 & \multirow{2}{*}{$\begin{array}{l}\text { BJB06.01A, } \\
\text { PAC }\end{array}$} & \multirow[t]{2}{*}{ Dawes Arboretum, $\mathrm{OH}$} & \\
\hline & $1.44+/-0.011$ & $\mathrm{R}$ & 706 & & & \\
\hline & & & & $\begin{array}{l}\text { Neinhuis 113, } \\
\text { DR }\end{array}$ & BG Dresden & JX485570 \\
\hline $\begin{array}{l}\text { Aristolochia triactina } \\
\text { (Hook. f.) Hutch \& } \\
\text { Dalz. }\end{array}$ & $4.39+/-0.059$ & $\mathrm{~S}$ & 4302 & $\begin{array}{c}\text { Neinhuis 119, } \\
\text { DR }\end{array}$ & BG Dresden & DQ532066 \\
\hline \multirow{4}{*}{$\begin{array}{l}\text { Aristolochia trilobata } \\
\mathrm{L} \text {. }\end{array}$} & $0.91+/-0.002$ & \multirow[t]{3}{*}{$S$} & 446 & BJB04.04A, & Kartuz Greenhouses, CA & \\
\hline & $0.99+/-0.010$ & & 485 & & & \\
\hline & $1.01+/-0.002$ & & 495 & & & \\
\hline & $1.02+/-0.004$ & $\mathrm{R}$ & 500 & & & \\
\hline Asarum canadense & $10.19+/-0.040$ & $S$ & 4993 & BJB04.03A, & Joel McNeal, (private coll.) & \\
\hline L. & $9.97+/-0.083$ & & 4885 & & & \\
\hline & $11.04+/-0.307$ & & 5410 & & & \\
\hline
\end{tabular}


Table 4 Genome sizes, vouchers, sources, and accessions for sequence data used (Continued)

\begin{tabular}{lcccc}
\hline Saruma henryi Oliv. & $6.12+/-0.044$ & $T$ & 2999 & $\begin{array}{c}\text { BJB06.08A, } \\
\text { PAC }\end{array}$ \\
\cline { 2 - 5 } & & & Neinhuis 120, \\
DR & Neinhuis 121, & India, Kerala, BG Dresden \\
\hline $\begin{array}{l}\text { Thottea siliquosa } \\
\text { (Lam.) Hou }\end{array}$ & $1.25+/-0.018$ & $S$ & 613 & JN415679
\end{tabular}

Abbreviations: R, Rice (Oryza sativa ssp. japonica cv. 'Nipponbare' 0.9 pg/2C); S, Soybean (Glycine max cv. 'Dunbar' 2.35 pg/2C), T, Tobacco (Nicotiana tabacum cv.'SR-1' 9.15 pg/2C); BG, Botanical Garden; PAC, Pennsylvania State University; DR, Dresden. Mbp DNA for plant species is based on the assumption 1pg=980 Mbp according to [118]. (BJB indicates first author).

\section{Genome sizing}

Nuclear genome size estimations were obtained by flow cell cytometry following the protocol described by Arumuganathan and Earle [119]. The mean nuclear DNA content of each plant sample (expressed as pg) was based on 1000 scanned nuclei from sample tissue, compared to a preparation of tissue from the internal standard. Each nuclear preparation was sampled four times.

\section{Phylogenetic analysis}

To clarify the phylogenetic positions of the taxa surveyed and to evaluate genome size in an evolutionary context we constructed a phylogenetic tree based on the plastid $\operatorname{trn} K$ intron and $m a t K$ gene region. Total DNA was extracted using the CTAB method [120]. Vouchers, DNA, and tissue samples are stored at PAC. Amplification and sequencing was performed following methods described in detail by Wanke et al. [14] using published primers $[14,18,121]$. Sequences were manually aligned using PhyDE $^{\circledR}$ [122]. Phylogenetic analysis was performed under maximum parsimony in PAUP* 4.0b10 [123] using PAUP scripts written by PRAP [124]. PRAP was used to implement the Parsimony Ratchet [125] following procedures described in Wanke et al. [14] but with 1000 ratchet replicates. Bootstrap values were additionally calculated to infer branch support with 1000 replicates. For an independent evaluation of relationships, a likelihood approach was chosen using the likelihood ratchet described by Morrison [126] as implemented in PRAP v. 2.0 [124] with default settings. A phylogram of the single maximum likelihood tree discovered with these methods indicates minimal branch length variation among the sampled Aristolochia species (Additional file 1: Phylogram of Aristolochiaceae relationships).

\section{Pollination experiments}

Several species of Aristolochia had been reported to be self-compatible (A. fimbriata, A. elegans, A. ridicula, $A$. ringens) and generally protogynous [42], having a receptive stigma before the anthers dehisce. To determine if autogamous pollination could be successful, we attempted hand pollinations of $A$. elegans and A. fimbriata on day one (the day of anthesis), day two, day three, day four and day five. Unopened flower buds were covered with pollination bags prior to anthesis and observed daily. Hand pollination methods are detailed in Additional file 2: Cultivation Supplement. Pollinations were accomplished by severing the perianth midway across the utricle, just above the gynostemium (Additional file 2: Figure S2A). Pollen was transferred with a toothpick (Additional file 2: Figure $\mathrm{S} 2 \mathrm{~B}$ ), and the remnant of the perianth was taped closed to prevent additional pollinator entry. Mature fruits (Additional file 2: Figure S2A) were collected and seeds germinated on wet toweling at $27^{\circ} \mathrm{C}$ exposed to $16 / 8 \mathrm{~h}$ day/night cycles.

\section{Genetic transformation}

A protocol for genetic transformation of $A$. fimbriata was developed based on in vitro shoot regeneration [47] from leaf and stem explants coupled with Agrobacteriummediated transformation. Leaf and internodal stem segments (2-3 cm long) from rooted tissue cultured $A$. fimbriata plants were excised and immediately immersed in induction media [46] to keep moist. The explants were inoculated with Agrobacterium strain AGL containing plasmid pGH00.0131 as previously described for Theobroma cacao L. [46]. After the inoculation the explants were blotted on sterile paper towels and co-cultivated on callus initiation medium (CI) [47] (0.5 mg/L 6BA, $1 \mathrm{mg} / \mathrm{L}$ NAA and $1 \mathrm{mg} / \mathrm{L}$ TDZ) for $64 \mathrm{~h}$ in the dark at $27^{\circ} \mathrm{C}$. Following co-cultivation, the explants were transferred to $\mathrm{CI}$ supplemented with $50 \mathrm{mg} / \mathrm{L}$ Geneticin (G418) (Cellgro, Herndon, VA) and $200 \mathrm{mg} / \mathrm{L}$ Claforan (Aventis, New Jersey) and incubated at $27^{\circ} \mathrm{C}$ in the dark for the remainder of the 14 days. After culture on CI medium, the explants were transferred to shoot regeneration medium (1.75 mg/L 6BA and $1.0 \mathrm{mg} / \mathrm{L}$ NAA) with $25 \mathrm{mg} / \mathrm{L} \mathrm{G418}$ and $200 \mathrm{mg} / \mathrm{L}$ Claforan and incubated in the dark for an additional 14 days. After the 28 days, the cultures were incubated under dim light until the development of shoot primordia. Individual glowing shoot primordia were then excised and transferred to REN2 medium (hormone free) in culture vessels (Sweetheart DSD8X and LDS58) under dim light conditions at $27^{\circ} \mathrm{C}$ [47] where they were maintained for further shoot elongation and rooting. EGFP 
fluorescence was observed and recorded as previously described [46]. Expression of red fluorescent protein in cells regenerating from transformed calli was independently observed in experiments by David Tricoli, U. C. Davis (personal communication).

\section{Genomic PCR analysis}

The incorporation of the transgenes was confirmed by genomic PCR. A set of EGFP specific PCR primers were used for the analysis. The primers amplify a $427 \mathrm{bp} \mathrm{EGFP} \mathrm{frag-}$ ment (5'-CCA GGA GCG CAC CAT CTT CT-3' and 5'CTC GTC CAT GCC GAG AGT GA-3' [46]. Genomic DNA was isolated from non-transgenic Aristolochia leaf tissue and from transgenic calli from independent lines using a CTAB method [120]. Each PCR reaction (final volume of $20 \mu \mathrm{l}$ ) contained: $5 \mathrm{ng}$ DNA (Qiagen purified DNA kit \#69104), $10 \mu \mathrm{l} \mathrm{JumpStart}{ }^{\text {tm }}$ REDTaq $^{\circledR}$ ReadyMix (Sigma \#0982), $5 \mu \mathrm{ls}$ water, forward and reverse primers at final concentration $0.5 \mu \mathrm{M}$. Reactions were prepared on ice. Control PCR reactions were also performed with $1 \mathrm{ng}$ plasmid DNA from vector pGH00.0131 and PCR reaction mix without DNA. This represents an equal molar amount of plasmid DNA compared to the EGFP DNA contained in 5 ng total Aristolochia genomic DNA present in the leaf extract, assuming single copy/insertion of the EGFP gene. For the plasmid reactions, DNA was isolated using QIAGEN plasmid midi purification kit (QIAGEN Inc., Valencia, CA). PCR conditions for all reactions were: $94^{\circ} \mathrm{C}$ for $2 \mathrm{~min}$, then 35 cycles of $94^{\circ} \mathrm{C}$ for 45 sec., $62^{\circ} \mathrm{C}$ for 45 sec, $72^{\circ} \mathrm{C}$ for $1 \mathrm{~min}$. The final cycle was followed by incubation at $72^{\circ} \mathrm{C}$ for $7 \mathrm{~min} .5 \mu \mathrm{l}$ of each PCR reaction were loaded onto $1.5 \%$ high-resolution agarose gel (SigmaAldrich Co., St. Louis, MO, \#A-4718) for electrophoresis.

\section{Expressed sequence EST datasets}

To support evolutionary and functional studies in Aristolochia and related taxa, an extensive database of expressed gene sequences was produced for Aristolochia fimbriata by the Ancestral Angiosperm Genome Project (http://ancangio.uga.edu/). Seeds of second generation selfed individuals were germinated in a greenhouse to widely sample plant organs and developmental stages under standard growth conditions (see Additional file 2: Cultivation Supplement). RNAs were isolated using the RNAqueous ${ }^{\mathbb{B}}$-Midi kit (Ambion, catalog \#1911) following the manufacturer's protocol (http://tools.invitrogen.com/content/sfs/manuals/ cms_055263.pdf) with modifications as described in Carlson et al. [127]. Details of library preparation, RNA and cDNA quality control steps, and Sanger and 454flx sequencing will be described elsewhere.

Sequences from individual 454 libraries were extracted from SFF files and renamed to reflect the source material. The names of Sanger sequences also indicated the source library. After renaming, all sequences were combined into a single fasta file. All sequences in the combined fasta file were screened for contaminants and trimmed using seqclean (http://compbio.dfci.harvard. edu/tgi/software/) with the Roche library adaptors, the Piper cenocladum chloroplast genome (NCBI accession NC_008457), mitochondrial gene sequences from magnoliids Calycanthus floridus, Liriodendron tulipifera, Laurus nobilis, Piper betle and Asarum sp. Qiu 96018, and the Univec database (http://www.ncbi.nlm.nih.gov/ VecScreen/UniVec.html). After screening and trimming, the 454 and Sanger sequences were assembled using MIRA version 3.0.5 (http://sourceforge.net/apps/ mediawiki/mira-assembler) [128], with default settings for EST sequences. The resulting unpadded consensus sequences (i.e. unigenes) were compared to seven angiosperm proteomes using blastx. All sequences and assemblies are available at http://ancangio.uga. edu/content/aristolochia-fimbriata. Assemblies and blast results can be viewed through http://ancangio.uga.edu/ ng-genediscovery/aristolochia.jnlp and the assembly can be searched using the Ancestral Angiosperm Genome Project blast interface at http://jlmwiki.plantbio.uga.edu/ blast/blast.html.

\section{Additional files}

\section{Additional file 1: Phylogram of Aristolochiaceae relationships. Maximum likelihood analyses showing minimal variation in branch lengths within Aristolochiaceae. Only one maxium likelihood tree was found. \\ Additional file 2: Cultivation Supplement. Description of perianth maturation, hand pollination methods, and self-compatibility in $A$. fimbriata and A. elegans includes: Figure S1 - Aristolochia fimbriata flower stages. Figure S2 - Hand pollination of A. fimbriata. Table S1 - Evaluating self-compatibility in Aristolochia fimbriata. Table S2 - Fruit set in Aristolochia elegans resulting from hand pollination. \\ Additional file 3: Maximum likelihood analysis of orthologs for alpha-galactosidase (ATAGAL1; AT5G08380). Blue star indicates a gene duplication in a common ancestor of angiosperms. \\ Additional file 4: Maximum likelihood analysis of orthologs for MYB-domain protein ASYMMETRIC LEAVES 1 (AS1; AT2G37630). Blue star indicates a gene duplication in a common ancestor of angiosperms, while the green star indicates a gene duplication in $A$. fimbriata.}

\section{Competing interests}

The authors declare they have no competing interests.

\section{Authors' contributions}

BB and SW contributed equally to the manuscript, specified criteria for a model system, provided herbarium material, tissue, and DNA vouchers, generated capillary sequence data and drafted the manuscript. BB developed hand pollination methods and inbred lines; specified tissue sampling for A. fimbriata libraries and developed transformation protocols. SW performed phylogenetic analyses. LL constructed A. fimbriata CDNA libraries for EST sequencing and contributed to transformation protocol development. LL and SW performed PCR verification of transformation. SWC generated EST sequence data, and SA, NW, AB, PKW, YJ, and JLM analyzed sequence data. YH performed tissue collection, RNA isolations, and contributed to transformation protocol development. PR performed tissue collections and RNA isolations and performed pollination and seed 
germination experiments. KA obtained cell flow cytometric estimates of genome sizes. CN contributed plant material and images and assisted in discussion of a basal angiosperm model plant. SNM contributed to transformation protocol development. HM participated in design and coordination and helped draft the manuscript. CWD conceived the study, and helped with experimental design and drafting the manuscript. All authors read and approved the final manuscript.

\section{Acknowledgements}

We thank A. Omeis for plant care, Jason Stetson and Yunjiao Joy Wang for DNA isolations, and Joel McNeal, Mario Blanco, Favio Gonzalez, Al Hill, Natalia PabonMora, Larry Rosen, Russ Strover, Victor Wong, the New York Botanical Garden, the Botanical Gardens at the University of Ulm, Dresden, Universidade de Coimbra, and Dawe's Arboretum for seed and plant material.

This work was supported in part by the NSF Plant Genome Research Program, awards DBI-0115684 (The Floral Genome Project) and DEB 0638595 (The Ancestral Angiosperm Genome Project), by the Department of Biology and Huck Institutes of Life Sciences of the Pennsylvania State University, and by a postdoctoral grant to SW from the German Academic Exchange Service (DAAD).

\begin{abstract}
Author details
${ }^{1}$ Department of Biology, Institute of Molecular Evolutionary Genetics, and the Huck Institutes of the Life Sciences, 201 Life Sciences Building, Pennsylvania State University, University Park, PA 16802, USA. ${ }^{2}$ USDA ARS PBARC, 64 Nowelo St., Hilo, HI 96720, USA. ${ }^{3}$ Technische Universität Dresden, Institut für Botanik, D-01062, Dresden, Germany. ${ }^{4} 100$ Jordan Hall, Clemson University, Clemson, SC 29634, USA. ${ }^{5}$ Department of Plant Sciences, University of Georgia, Athens, GA 30602, USA. 'Chicago Botanic Garden, Glencoe, IL 27709, USA. ${ }^{7}$ BASF Plant Science, 26 Davis Drive, Research Triangle Park, NC 27709, USA. ${ }^{8}$ Benaroya Research Institute at Virginia Mason, Flow Cytometry and Imaging Core Laboratory, 1201 Ninth Avenue, Seattle, WA 98101, USA. 9 The Genome Institute,Washington University School of Medicine, 4444 Forest Park Boulevard, St. Louis, MO 63108, USA. ${ }^{10}$ Stephenson Research and Technology Center, Advanced Center for Genome Technology, University of Oklahoma, 101 David L. Boren Blvd, Norman, OK 73019, USA. ${ }^{11}$ Department of Horticulture, 421 Life Sciences Building, Pennsylvania State University, University Park, PA 16802, USA. ${ }^{12}$ State Key Laboratory of Genetic Engineering and the Institute of Plant Biology, the Center for Evolutionary Biology, the School of Life Sciences, Fudan University, Shanghai 200433, China. ${ }^{13}$ Institutes of Biomedical Sciences, Fudan University, Shanghai 200032, China.
\end{abstract}

Received: 24 May 2012 Accepted: 12 December 2012 Published: 24 January 2013

\section{References}

1. Bolker JA: Model systems in developmental biology. BioEssays 1995 17(5):451-455.

2. Kellogg EA, Shaffer HB: Model organisms in evolutionary studies. Syst Biol 1993, 42(4):409-414.

3. Soltis DE, Soltis PS, Albert VA, Oppenheimer DG, de Pamphilis CW, Ma H, Frohlich MW, Theissen G: Missing links: the genetic architecture of flower and floral diversification. Trends Plant Sci 2002, 7(1):22-31.

4. Pryer KM, Schneider H, Zimmer EA, Banks JA: Deciding among green plants for whole genome studies. Trends Plant Sci 2002, 7:550-554.

5. Kelly L, Leitch I: Exploring giant plant genomes with next-generation sequencing technology. Chromosome Res 2011, 19(7):939-953.

6. Baum DA, Doebley J, Irish VF, Kramer EM: Response: missing links: the genetic architecture of flower and floral diversification. Trends Plant Sci 2002, 7(1):31-34

7. Jansen RK, Cai Z, Raubeson LA, Daniell H, de Pamphilis CW, Leebens-Mack J, Muller KF, Guisinger-Bellian M, Haberle RC, Hansen AK, et al: Analysis of 81 genes from 64 plastid genomes resolves relationships in angiosperms and identifies genome-scale evolutionary patterns. Proc Natl Acad Sci U S A 2007, 104(49):19369-19374.

8. Moore MJ, Bell CD, Soltis PS, Soltis DE: Using plastid genome-scale data to resolve enigmatic relationships among basal angiosperms. Proc Natl Acad Sci U S A 2007, 104(49):19363-19368.

9. Stevens PF: Angiosperm Phylogeny Website Version 9, June 2008 [and more or less continuously updated since]. http://www.mobot.org/MOBOT/research/APweb/.
10. Zuccolo A, Bowers J, Estill J, Xiong Z, Luo M, Sebastian A, Goicoechea J, Collura K, Yu Y, Jiao Y, et al: A physical map for the Amborella trichopoda genome sheds light on the evolution of angiosperm genome structure. Genome Biology 2011, 12(5):R48.

11. Soltis DE, Albert VA, Leebens-Mack J, Palmer JD, Wing RA, de Pamphilis CW, $\mathrm{Ma} \mathrm{H}$, Carlson JE, Altman N, Kim S, et al: The Amborella genome: an evolutionary reference for plant biology. Genome Biology 2008, 9(3):402-407.

12. Liang HY, Fang EG, Tomkins JP, Luo MZ, Kudrna D, Kim HR, Arumuganathan K, Zhao SY, Leebens-Mack J, Schlarbaum SE, et al: Development of a BAC library for yellow-poplar (Liriodendron tulipifera) and the identification of genes associated with flower development and lignin biosynthesis. Tree Genet Genomes 2007, 3(3):215-225.

13. Awad M, Young RE: Post-harvest variation in cellulase, polygalacturonase, and pectinmethylesterase in avocado (Persea americana Mill, cv. Fuerte) fruits in relation to respiration and ethylene production. Plant Physiol 1979, 64(2):306-308.

14. Wanke S, Jaramillo MA, Borsch T, Samain MS, Quandt D, Neinhuis C: Evolution of Piperales-matK gene and trnK intron sequence data reveal lineage specific resolution contrast. Mol Phylogenet Evol 2007, 42(2):477-497.

15. Madrid E, Friedman N: Female gametophyte development in Aristolochia labiata Willd. (Aristolochiaceae). Bot J Linn Soc 2008, 158(1):19-29.

16. Soltis DE, Soltis PE, Endress PK, Chase MW: Phylogeny and Evolution of Angiosperms. Sunderland, MA: Sinauer Associates; 2005.

17. Mabberley DJ: The Plant Book. Cambridge, England: Cambridge University Press; 1997.

18. Wanke S, Gonzalez F, Neinhuis C: Systematics of pipevines: combining morphological and fast-evolving molecular characters to investigate the relationships within subfamily Aristolochioideae (Aristolochiaceae). Int J Plant Sci 2006, 167(6):1215-1227.

19. Endress PK: Angiosperm floral evolution: Morphological developmental framework. In Advances in Botanical Research: Incorporating Advances in Plant Pathology, Volume 44. Edited by Doug S, Pamela S, Jim L-M. London: Academic Press Ltd; 2006:1-61.

20. Endress PK, Igersheim A: Gynoecium structure and evolution in basal angiosperms. Int J Plant Sci 2000, 161(6):S211-S223.

21. Friedman WE, Williams JH: Developmental evolution of the sexual process in ancient flowering plant lineages. Plant Cell 2004, 16:S119-S132.

22. Williams $J H$, Friedman WE: Identification of diploid endosperm in an early angiosperm lineage. Nature 2002, 415(6871):522-526.

23. Floyd SK, Friedman WE: Developmental evolution of endosperm in basal angiosperms: evidence from Amborella (Amborellaceae), Nuphar (Nymphaeaceae), and Illicium (Illiciaceae). Plant Systemat Evol 2001, 228(3-4):153-169.

24. Buzgo M, Endress PK: Floral structure and development of Acoraceae and its systematic relationships with basal angiosperms. Int J Plant Sci 2000, 161(1):23-41.

25. Endress PK: Origins of flower morphology. J Exp Zool 2001, 291(2):105-115.

26. Irish VF: Duplication, diversification, and comparative genetics of angiosperm MADS-box genes. In Advances in Botanical Research: Incorporating Advances in Plant Pathology, Volume 44. Edited by Doug S, Pamela S, Jim L-M. London: Academic Press Ltd; 2006:129-161.

27. Endress PK: Diversity and Evolutionary Biology of Tropical Flowers. 1st pbk. ed. (with corrections). Cambridge: Cambridge University Press; 1994.

28. Ma H, de Pamphilis C: The ABCs of floral evolution. Cell 2000, 101(1):5-8.

29. Coen ES, Meyerowitz EM: The war of the whorls: genetic interactions controlling flower development. Nature 1991, 353(6339):31-37.

30. Theissen G: Development of floral organ identity: stories from the MADS house. Curr Opin Plant Biol 2001, 4(1):75-85.

31. Endress PK: Flower development and evolution viewed from a diversity perspective. In Botany and Plant Biology (Abstract 1161): July 9, 2007. Edited by Doug S, Pamela S, Jim L-M. Chicago, IL USA: American Society of Plant Biologists; 2007.

32. Soltis PS, Soltis DE, Kim S, Chanderbali A, Buzgo M: Expression of floral regulators in basal angiosperms and the origin and evolution of $A B C$ function. In Advances in Botanical Research: Incorporating Advances in Plant Pathology, Volume 44. Edited by Doug S, Pamela S, Jim L-M. London: Academic Press Ltd; 2006:483-506.

33. Buzgo M, Soltis DE, Soltis PS, Ma H: Towards a comprehensive integration of morphological and genetic studies of floral development. Trends Plant Sci 2004, 9(4):164-173. 
34. Jansson S, Douglas CJ: Populus: a model system for plant biology. Annu Rev Plant Biol 2007, 58(1):435-458.

35. Albert VA, Soltis DE, Carlson JE, Farmerie WG, Wall PK, llut DC, Solow TM, Mueller $L A$, Landherr $L L, H u Y$, et al: Floral gene resources from basal angiosperms for comparative genomics research. BMC Plant Biology 2005, 5(1):15.

36. Wei FS, Wing RA: A fruitful outcome to the papaya genome project. Genome Biol 2008, 9(6):4.

37. Neinhuis C, Wanke S, Hilu KW, Muller K, Borsch T: Phylogeny of Aristolochiaceae based on parsimony, likelihood, and Bayesian analyses of trnL-trnF sequences. Plant Systemat Evol 2005, 250(1-2):7-26.

38. Bennett M, Leitch I: Angiosperm DNA C-values Database (release 4.0, October 2005). http://data.kew.org/cvalues/homepage.html.

39. Cui L, Wall PK, Leebens-Mack JH, Lindsay BG, Soltis DE, Doyle JJ, Soltis PS, Carlson JE, Arumuganathan K, Barakat A, et al: Widespread genome duplications throughout the history of flowering plants. Genome Res 2006, 16(6):738-749.

40. Arabidopsis $\mathrm{Gl}$ : Analysis of the genome sequence of the flowering plant Arabidopsis thaliana. Nature 2000, 408(6814):796-815.

41. International-Rice-Genome-Sequencing-Project: The map-based sequence of the rice genome. Nature 2005, 436(7052):793-800

42. Petch T: Notes on Aristolochia. Annals of the Royal Botanic Gardens, Peradeniya 1924, VIII:1-108.

43. Ohi-Toma T, Sugawara T, Murata H, Wanke S, Neinhuis C, Murata : Molecular phylogeny of Aristolochia sensu lato (Aristolochiaceae) based on sequences of $r b c L$, matK, and phyA genes, with special reference to differentiation of chromosome numbers. Syst Bot 2006, 31(3):481-492.

44. Sugawara T: Chromosome number of Saruma henryi Oliver Aristolochiaceae. Bot Mag Tokyo 1987, 100(1057):99-102.

45. Müller J, Müller K: TreeGraph: Automated drawing of complex tree figures using an extensible tree description format. Mol Ecol Notes 2004, 4(4):786-788.

46. Maximova S, Miller C, Antunez de Mayolo G, Pishak S, Young A, Guiltinan MJ: Stable transformation of Theobroma cacao L. and influence of matrix attachment regions on GFP expression. Plant Cell Rep 2003, 21(9):872-883

47. Bliss BJ, Landherr $L$, de Pamphilis $C W, M a ~ H, H u ~ Y$, Maximova SN: Regeneration and plantlet development from somatic tissues of Aristolochia fimbriata. Plant Cell Tiss Org Cult 2009, 98:105-114.

48. Glass flowers from the Ware collection in the Botanical Museum of Harvard University. New York: Harcourt, Brace and Company; 1940.

49. Gonzalez F, Stevenson DW: Perianth development and systematics of Aristolochia. Flora 2000, 195(4):370-391.

50. Gonzalez F, Stevenson DW: Gynostemium development in Aristolochia (Aristolochiaceae). Bot Jahrb Syst 2000, 122(2):249-291.

51. Cubas P, Coen E, Zapater JM: Ancient asymmetries in the evolution of flowers. Curr Biol 2001, 11(13):1050-1052.

52. Feng $X$, Zhao Z, Tian Z, Xu S, Luo Y, Cai Z, Wang Y, Yang J, Wang Z, Weng $L$, et al: Control of petal shape and floral zygomorphy in Lotus japonicus. Proc Natl Acad Sci U S A 2006, 103(13):4970-4975.

53. Dickison WC: Morphology and anatomy of the flower and pollen of Saruma henryi Oliv., a phylogenetic relict of the Aristolochiaceae. Bull Torrey Bot Club 1992, 119(4):392-400.

54. Dickison WC: Stem and Leaf Anatomy of Saruma henryi Oliv., Including Observations on Raylessness in the Aristolochiaceae. Bull Torrey Bot Club 1996, 123(4):261-267

55. Gonzales F, Rudall P: Structure and development of the ovule and seed in Aristolochiaceae, with particular reference to Saruma. Plant Systemat Evol 2003, 241:223-244

56. Gonzalez F, Rudall PJ, Furness CA: Microsporogenesis and systematics of Aristolochiaceae. Bot J Linnean Soc 2001, 137(3):221-242.

57. Madrid EN, Friedman WE: The developmental basis of an evolutionary diversification of female gametophyte structure in Piper and Piperaceae. Ann Bot 2009, 103(6):869-884

58. Gonzalez F: Inflorescence morphology and the systematics of Aristolochiaceae. Syst Geogr Pl 1999, 68(1-2):159-172.

59. Irish VF: The evolution of floral homeotic gene function. Bioessays 2003, 25(7):637-646.

60. de Craene LPR, Soltis PS, Soltis DE: Evolution of floral structures in basal angiosperms. Int J Plant Sci 2003, 164(5):S329-S363.

61. Kramer EM, Irish VF: Evolution of the petal and stamen developmental programs: evidence from comparative studies of the lower eudicots and basal angiosperms. Int J Plant Sci 2000, 161(6):S29-S40.
62. Zhao Y, Wang G, Zhang J, Yang J, Peng S, Gao L, Li C, Hu J, Li D, Gao L: Expressed sequence tags (ESTs) and phylogenetic analysis of floral genes from a paleoherb species, Asarum caudigerum. Ann Bot 2006, 98(1):157-163.

63. Leins $P$, Erbar C: Contribution to floral development in Aristolochiaceae: a link to the monocotyledons. Bot Jahrb Syst 1985, 107:343-368.

64. Renuka C, Swarupanandan K: Morphology of the flower in Thottea siliquosa and the existence of staminodes in Aristolochiaceae. Blumea 1986, 31(2):313-318.

65. Sugawara T: Taxonomic studies of Asarum sensu lato III. Comparative floral anatomy. Bot Mag Tokyo 1987, 100(1060):335-348.

66. Leins P, Erbar C, Van Heel WA: Note on the floral development of Thottea Aristolochiaceae. Blumea 1988, 33(22):357-370.

67. Jaramillo MA, Kramer EM: APETALA3 and PISTILLATA homologs exhibit novel expression patterns in the unique perianth of Aristolochia (Aristolochiaceae). Evol Dev 2004, 6(6):449-458.

68. Kramer EM, Irish VF: Evolution of genetic mechanisms controlling petal development. Nature 1999, 399(6732):144-148.

69. Zahn LM, Leebens-Mack J, de Pamphilis CW, Ma H, Theissen G: To B or not to $\mathrm{B}$ a flower: the role of DEFICIENS and GLOBOSA orthologs in the evolution of the angiosperms. J Hered 2005, 96(3):225-240.

70. Kumar V, Poonam, Prasad AK, Parmar VS: Naturally occurring aristolactams, aristolochic acids and dioxoaporphines and their biological activities. Nat Prod Rep 2003, 20(6):565-583.

71. Heinrich M, Chan J, Wanke S, Neinhuis C, Simmonds MSJ: Local uses of Aristolochia species and content of nephrotoxic aristolochic acid 1 and 2 - A global assessment based on bibliographic sources. J Ethnopharmacol 2009, 125(1):108-144.

72. Pakrashi A, Pakrasi P: Anti-fertility efficacy of the plant Aristolochia indica (Linn) on mouse. Contraception 1979, 20(1):49-54.

73. Shafi PM, Rosamma MK, Jamil K, Reddy PS: Antibacterial activity of the essential oil from Aristolochia indica. Fitoterapia 2002, 73(5):439-441.

74. Elizabeth KM, Raju CS: Antimicrobial activity of Aristolochia bracteata. Asian J Chem 2006, 18(1):207-211.

75. Broussalis AM, Ferraro GE, Martino VS, Pinzon R, Coussio JD, Alvarez JC Argentine plants as potential source of insecticidal compounds. J Ethnopharmacol 1999, 67(2):219-223.

76. Gadhi CA, Benharref A, Jana M, Lozniewski A: Anti-Helicobacter pylori activity of Aristolochia paucinervis Pomel extracts. J Ethnopharmacol 2001, 75(2-3):203-205.

77. Gupta RS, Dobhal MP, Dixit VP: Morphometric and biochemical changes in testes of Presbytis entellus entellus Dufresne (Langur monkey) following aristolochic acid administration. Ann Biol (Ludhiana) 1996, 12(2):328-334

78. Qiu Q, Liu ZH, Chen HP, Yin HL, Li LS: Long-term outcome of acute renal injury induced by Aristolochia. Acta Pharm Sin 2000, 21(12):1129-1135.

79. Meinl W, Pabel U, Osterloh-Quiroz M, Hengstler JG, Glatt H: Human sulphotransferases are involved in the activation of aristolochic acids and are expressed in renal target tissue. Int J Cancer 2006, 118(5):1090-1097.

80. Otero R, Nunez V, Barona J, Fonnegra R, Jimenez SL, Osorio RG, Saldarriaga M, Diaz A: Snakebites and ethnobotany in the northwest region of Colombia Part III: neutralization of the haemorrhagic effect of Bothrops atrox venom. J Ethnopharmacol 2000, 73(1-2):233-241.

81. Hwang MS, Park MS, Moon J-Y, Lee JS, Yum YN, Yoon E, Lee H, Nam KT, Lee BM, Kim SH, et al: Subchronic toxicity studies of the aqueous extract of Aristolochiae fructus in Sprague-Dawley rats. J Toxicol Environ Health 2006, 69(24):2157-2165

82. Grollman AP, Shibutani S, Moriya M, Miller F, Wu L, Moll U, Suzuki N, Fernandes A, Rosenquist T, Medverec $Z$, et al: Aristolochic acid and the etiology of endemic (Balkan) nephropathy. Proc Natl Acad Sci USA 2007, 104(29):12129-12134.

83. Lindner E: Aristolochia lindneri Berger und ihre Bestäubung durch Fliegen. Biol Zbl 1928, 48(2):93-101.

84. Hall DW, Brown BV: Pollination of Aristolochia littoralis (Aristolochiales: Aristolochiaceae) by males of Megaselia spp. (Diptera: Phoridae). Ann Entomol Soc Am 1993, 86(5):609-613.

85. Wolda H, Sabrosky CW: Insect visitors to two forms of Aristolochia pilosa in Las Cumbres Panama. Biotropica 1986, 18(4):295-299.

86. Lu KL: Pollination biology of Asarum caudatum (Aristolochiaceae) in Northern California. Syst Bot 1982, 7(2):150-157.

87. Oelschlägel B, Gorb S, Wanke S, Neinhuis C: Structure and biomechanics of trapping flower trichomes and their role in pollination biology in 
Mediterranean Aristolochia plants (Aristolochiaceae). New Phytol 2009, 184:988-1002

88. Vogel S: Fungus-gnat flowers mimicking fungi Part 1. Flora 1978 167(3-4):329-366.

89. Sakai S: Aristolochia spp. (Aristolochiaceae) pollinated by flies breeding on decomposing flowers in Panama. Am J Bot 2002, 89(3):527-534.

90. Disney RHL, Sakai S: Scuttle flies (Diptera: Phoridae) whose larvae develop in flowers of Aristolochia (Aristolochiaceae) in Panama. Eur J Entomol 2001, 98(3):367-373.

91. Burgess KS, Singfield J, Melendez V, Kevan PG: Pollination biology of Aristolochia grandiflora (Aristolochiaceae) in Veracruz, Mexico. Ann Mo Bot Gard 2004, 91(2):346-356.

92. Rulik B, Wanke S, Nuss M, Neinhuis C: Pollination of Aristolochia pallida Willd. (Aristolochiaceae) in the Mediterranean. Flora 2008, 203:175-184.

93. Fordyce JA, Marion ZH, Shapiro AM: Phenological variation in chemical defense of the pipevine swallowtail, Battus philenor. J Chem Ecol 2005, 31(12):2835-2846.

94. De Morais ABB, Brown KS Jr: Larval foodplant and other effects on troidine guild composition (Papilionidae) in southeastern Brazil. J Res Lepid 1991, 30(1-2):19-37.

95. Klitzke CF, Brown KS Jr: The occurrence of aristolochic acids in neotropical troidine swallowtails (Lepidoptera: Papilionidae). Chemoecology 2000, 10(2):99-102.

96. Nishida R, Fukami H: Ecological adaptation of an Aristolochiaceae-feeding swallowtail butterfly Atrophaneura alcinous to aristolochic acids. J Chem Ecol 1989, 15(11):2549-2564.

97. Nishida R: Oviposition stimulant of a Zeryntiine swallowtail butterfly, Luehdorfia japonica. Phytochemistry 1994, 36(4):873-877.

98. Rausher MD: Host plant selection by Battus philenor butterflies: The roles of predation, nutrition, and plant chemistry. Ecol Monogr 1981, 51(1):1-20.

99. Sands DPA, Scott SE, Moffatt R: The threatened Richmond birdwing butterfly (Ornithoptera richmondia (Gray)): a community conservation project. Mem Mus Vic 1997, 56(2):449-453.

100. Palacios SM, Maggi ME, Bazan CM, Carpinella MC, Turco M, Munoz A, Alonso RA, Nunez C, Cantero JJ, Defago MT, et al: Screening of Argentinian plants for pesticide activity. Fitoterapia 2007, 78:580-584

101. Alexenizer M, Dorn A: Screening of medicinal and ornamental plants for insecticidal and growth regulating activity. J Pest Sci 2007, 80:205-215.

102. Lajide L, Escoubas P, Mizutani J: Antifeedant activity of metabolites of Aristolochia albida against the tobacco cutworm, Spodoptera litura. J Agric Food Chem 1993, 41(4):669-673.

103. Isnard S, Prosperi J, Wanke S, Wagner S, Trueba S, Frenzke L, Samain M-S, Neinhuis C, Rowe NP: Growth form evolution in angiosperms: patterns of stem development, anatomy, biomechanics and architecture within the Piperales. Int J Plant Sci 2012, 173(6):610-639. In: Special Issue: Major transitions in angiosperm ecology and functional biology (eds. Field T., Edwards E.).

104. Lahaye R, Civeyrel L, Speck T, Rowe NP: Evolution of shrub-like growth forms in the lianoid subfamily Secamonoideae (Apocynaceae s.l.) of Madagascar: phylogeny, biomechanics, and development. Am J Bot 2005, 92:1381-1396.

105. Rowe NP, Speck T: Plant growth forms: an ecological and evolutionary perspective. New Phytol 2005, 166:61-72.

106. Taylor DW, Hickey LJ: An Aptian plant with attached leaves and flowers: implications for angiosperm origin. Science 1990, 247(4943):702-704

107. Taylor DW, Hickey LJ: Phylogenetic evidence for the herbaceous origin of angiosperms. Plant Systemat Evol 1992, 180(3-4):137-156.

108. Huber H: Aristolochiaceae. In The Families and Genera of Vascular Plants. Edited by Kubitzki K, Rohwer JG, Bittrich V. Berlin: Springer; 1993:129-137.

109. Behnke HD: Sieve-element plastids and evolution of monocotyledons, with emphasis on Melanthiaceae sensu lato and Aristolochiaceae Asaroideae, a putative dicotyledon sister group. Bot Rev 2003, 68(4):524-544.

110. Duvall MR: Seeking the dicot sister group of the monocots. In Monocots: Systematics and Evolution Proceedings of the Second International Conference on the Comparative Biology of the Monocots. Edited by Wilson KL, Morrison DA. Melbourne: CSIRO; 2000:25-32.

111. Leins $P$, Erbar $C$ : The early pattern of differentiation in the flowers of Saruma henryi Oliv. (Aristolochiaceae). Bot Jahrb Syst 1995, 117(3):365-376.

112. Kelly LM: Phylogenetic relationships in Asarum (Aristolochiaceae) based on morphology and ITS sequences. Am J Bot 1998, 85(10):1454-1467.
113. Jones-Rhoades MW, Bartel DP, Bartel B: MicroRNAs and their regulatory roles in plants. Ann Rev Plant Biol 2006, 57:19-53.

114. Barakat A, Wall K, Wang J, Carlson J, Leebens-Mack J, de Pamphilis C Identification and distribution of microRNAs from a basal eudicot (Eschscholzia californica) and two basal angiosperm species (Nuphar advena and Aristolochia fimbriata). In Plant \& Animal Genomes XV Conference (Abstract P227: General Comparative): January 13-17, 2007. Edited by. San Diego, CA: Town \& Country Convention Center; 2007.

115. Axtell MJ, Snyder JA, Bartell DP: Common functions for diverse small RNAs of land plants. Plant Cell 2007, 19(6):1750-1769.

116. Barakat A, Wall K, Leebens-Mack J, Wang YJ, Carlson JE, Depamphilis CW: Large-scale identification of microRNAs from a basal eudicot (Eschscholzia californica) and conservation in flowering plants. Plant J 2007, 51:991-1003

117. Burch-Smith TM, Anderson JC, Martin GB, Dinesh-Kumar SP: Applications and advantages of virus-induced gene silencing for gene function studies in plants. Plant J 2004, 39(5):734-746.

118. Wang W, Tanurdzic M, Luo M, Sisneros N, Kim HR, Weng JK, Kudrna D, Mueller C, Arumuganathan K, Carlson J, et al: Construction of a bacterial artificial chromosome library from the spikemoss Selaginella moellendorffii: a new resource for plant comparative genomics. BMC Plant Biol 2005, 5(1):10.

119. Arumuganathan K, Earle E: Estimation of nuclear DNA content of plants by cell-flow cytometry. Plant Mol Biol Rep 1991, 9(3):229-233.

120. McNeal JR, Leebens-Mack JH, Arumuganathan K, Kuehl JV, Boore JL, de Pamphilis CW: Using partial genomic fosmid libraries for sequencing complete organellar genomes. Biotechniques 2006, 41(1):69-73.

121. Wanke S, Quandt D, Neinhuis C: Universal primers for a large cryptically simple cpDNA microsatellite region in Aristolochia (Aristolochiaceae). Mol Ecol Notes 2006, 6(4):1051-1053.

122. Müller J, Müller K, Neinhuis C, Quandt D: PhyDE- A phylogenetic data editor. Version 0.92. In $P$ hyDE ${ }^{\circledR}$ is a registered trade mark of Jörn Müller. Edited by. 2007. Program distributed by the authors http://www.phyde.de.

123. Swofford DL: PAUP*. Phylogenetic Analysis Using Parsimony ( ${ }^{*}$ and other methods). 40b10th edition. Sunderland, Massachusetts: Sinauer Associates; 2002.

124. Müller K: PRAP - computation of Bremer support for large data sets. Mol Phylogenet Evol 2004, 31:780-782

125. Nixon KC: The parsimony ratchet, a new method for rapid parsimony analyses. Cladistics 1999, 15(4):407-414.

126. Morrison DA: Increasing the efficiency of searches for the maximum likelihood tree in a phylogenetic analysis of up to 150 nucleotide sequences. Syst Biol 2007, 56:988-1010.

127. Carlson JE, Leebens-Mack JH, Wall PK, Zahn LM, Mueller LA, Landherr LL, Hu Y, llut DC, Arrington JM, Chiorean S, et al: EST database for early flower development in California poppy (Eschscholzia californica Cham., Papaveraceae) tags over 6000 genes from a basal eudicot. Plant Mol Biol 2006, 62:351-369.

128. Chevreux B, Pfisterer T, Drescher B, Driesel AJ, Müller WEG, Wetter T, Suhai S: Using the miraEST assembler for reliable and automated mRNA transcript assembly and SNP detection in sequenced ESTs. Genome Res 2004, 14(6):1147-1159.

doi:10.1186/1471-2229-13-13

Cite this article as: Bliss et al:: Characterization of the basal angiosperm Aristolochia fimbriata: a potential experimental system for genetic studies. BMC Plant Biology 2013 13:13. 